\title{
Children at the Borders
}

\author{
Jonathan Josefsson
}

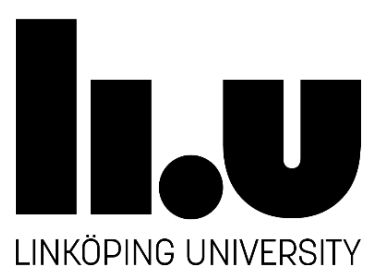

Linköping Studies in Arts and Science, No 706

Department of Thematic Studies - Child Studies

Linköping University, Sweden

Linköping 2016 
Linköping Studies in Arts and Science • No. 706

At the Faculty of Arts and Sciences at Linköping University, research and doctoral studies are carried out within broad problem areas. Research is organized in interdisciplinary research environments and doctoral studies mainly in graduate schools. Jointly, they publish the series Linköping Studies in arts and Science. This thesis comes from TEMA Barn, the Department of Thematic Studies - Child Studies.

Distributed by:

TEMA - the Department of Thematic Studies

Linköping University

58183 Linköping

Sweden

Jonathan Josefsson

Children at the Borders

Edition 1:1

ISBN 978-91-7685-602-4

ISSN 0282-980

(Jonathan Josefsson, 2016

TEMA - the Department of Thematic Studies

Printed by LiU-Tryck, Linköping, Sweden, 2016

Cover picture: Caroline Färnström 


\section{Acknowledgements}

To write this thesis had not been possible without all of you who have been involved in it along the way. Firstly, a special thanks to you, my supervisor Karin Zetterqvist Nelson. It feels like we started this work together from day one when you called me on my phone to let me know I was admitted as a doctoral student. Your devotion to research on children and childhood and to this project have been truly inspiring. I have appreciated your courage to try new routes, always with a sharp, sceptical and professional eye, but at the same time indeed encouraging. A special thanks also to you Göran Collste. I'm grateful for your critical reading, our stimulating discussions and all your support. Just as much as I have appreciated your academic skills, I have also learned from you the importance of having a well-deserved beer after a day of hard conference work.

The Department of Thematic Studies - Child Studies in Linköping has been a great place to work, think, discuss and write during these years. Thanks to all of you on the faculty who so generously have contributed with comments on drafts and have provided invaluable support: Kerstin Andersson, Mats Andrén, Disa Bergnér, Asta Cekaite Thunqvist, Karin Osvaldsson, Sofia Kvist Lindholm, Tobias Samuelsson, Bengt Sandin, Johanna Sjöberg, Anna Sparrman, Gunilla Tegern, Layal Viltgren and Anette Wickström. Judith Lind and Cecilia Lindgren, you read my manuscript carefully and constructively at the mid- and final seminar, and for that I'm grateful. And thanks to all of you doctoral student colleagues. Together we have created brilliant hits in the Tema basement, performed unforgettable shows on stages around Östergötland and lighted up the sometimes hard periods of work with good laughs and great company: Zulmir Becevic, David Cardell, Daniel Gustafsson, Johanna Gustafsson, Mirjam Hagström, Mathilda Hallberg, Malva Holm Kvist, Paul Horton, Yelyzaveta Hrechaniuk, Mina Kheirkhah, Sofia Littmarck, Elin Låby, Joel Löw, Sarah Mitchell, Mehek Muftee, Alex Orrmalm Auran, Åsa Pettersson, Johanna Sjöberg, Peter Skagius, Madeleine Wirzén, Emilia Zotevska and Eva-Marie Åkerlund. Thanks to the administrative staff at the Tema Department and a special thanks to Eva Danielson for your positive energy and Mikael Brandt for our chit chats by the coffee machine.

Hans Andersson, Johanna Schiratzki and Carl-Henric Grenholm, thank you for reading my manuscript. Leila Brännström, your wise, interesting and constructive reading of the manuscript at an important stage in the process has meant much to me. Martin Andersson, Maren Behrensen, Anders Nordgren, Elin Palm, Yusuf Yuksekdag, at the Center for Applied Ethics, I have always appreciated our discussions, readings and dinners. Over the last years I have had the opportunity to present parts of the thesis at the regular 
meetings of the Nordic Research School of Ethics, the Swedish Network for Political Theory and Societas Ethica - European Society for Research in Ethics, all of your comments and discussions have been valuable, thanks. Thanks also to the Netherlands Research School of Philosophy for letting me participate and present at your summer school, and particularly to you Hans Lindahl for inspiring theoretical discussions and valuable comments. Childhood Studies at Rutgers University, thanks to all of you, faculty and graduate students, for your hospitality and comments. John Wall, our discussions about childhood and philosophy, your generous welcome in Philadelphia and invigorating feedback on my drafts have inspired me greatly along the way. Markus Gunneflo, thank you for the encouragements and reading parts of the thesis. Tim Carter and Marie Clark Nelson, you have done a great job to enrich the language in the thesis, thanks.

And finally, but surely not least, thanks to all of you, family and friends. Mom and Dad, and Eia and Jan-Christer, a special thanks for your support. Lova and Axel, you are my sunshine and inspiration to do all those other things that are more important than writing a thesis. Petra, without you this would simply not have been possible. Thank you for everything. 


\section{CONTENTS}

List of Papers $\quad 7$

Abbreviations $\quad 8$

INTRODUCTION 9

$\begin{array}{ll}\text { Children's rights and immigration control } & 11\end{array}$

Aim and outline of the thesis 17

CHILDREN'S RIGHTS AS A SOCIO-POLITICAL PRACTICE 21

Children's rights and the UNCRC 22

Children's rights: from top-down to bottom-up 26

$\begin{array}{ll}\text { The socio-political practice of children's rights } & 27\end{array}$

CHILDREN'S RIGHTS AS POLITICAL PHILOSOPHY 33

The UNCRC and lack of theorisation 33

Political philosophy and the nature of childhood 34

$\begin{array}{ll}\text { Children's rights in political philosophy } & 37\end{array}$

Martha Nussbaum's capability approach $\quad 42$

Seyla Benhabib's discourse ethics 43

MIGRATION AND THE RIGHTS OF ASYLUM-SEEKING CHILDREN 47

$\begin{array}{ll}\text { A childhood turn in migration research } & 47\end{array}$

Asylum-seeking children between universal rights and immigration control 49

MATERIAL AND METHOD

Article one: the Swedish Migration Court of Appeal 61

Article two: Dagens Nyheter 64

Articles three and four: Martha Nussbaum's capability approach and Seyla Benhabib's discourse ethics $\quad 66$

SUMMARY OF ARTICLES

Article 1: Children's rights to asylum in the Swedish Migration Court of Appeal 69

Article 2: 'We beg you, let them stay!': right claims of asylum-seeking children as a socio-political practice $\quad 69$

Article 3: Children's rights to asylum and the capability approach $\quad 70$

Article 4: Right claims of asylum-seeking children: a discourse ethical approach $\quad 70$

$\begin{array}{ll}\text { DISCUSSION } & 73\end{array}$

$\begin{array}{ll}\text { REFERENCES } & 79\end{array}$ 



\section{LIST OF PAPERS}

I. Josefsson, Jonathan. 'Children's Rights to Asylum in the Swedish Migration Court of Appeal'. International Journal of Children's Rights (accepted).

II. Josefsson, Jonathan. “"We beg you, let them stay!”: right claims of asylum-seeking children as a socio-political practice'. Childhood. Prepublished 7 November 2016, DOI:10.1177/0907568216674785.

III. Josefsson, Jonathan. 'Children's Rights to Asylum and the Capability Approach'. Ethical Perspectives 23, No. 1 (2016): 101-30.

IV. Josefsson, Jonathan. 'Right claims of asylum-seeking children: a discourse ethical approach' (to be submitted). 


\section{ABBREVIATIONS}

MCA The Swedish Migration Court of Appeal (Swedish translation: Migrationsöverdomstolen)

DN Dagens Nyheter (English translation: Daily News)

SFS Svensk författningssamling (English translation: Swedish Code of Statutes

SOU Statens offentliga utredningar (English translation: Swedish Government Official Reports

PROP Proposition (English translation: Bill) 


\section{INTRODUCTION}

The final day to submit responses to the Swedish government's consultation on the draft proposal to restrict the possibility of getting residence permits in Sweden was 10 March 2016. ${ }^{1}$ Against the backdrop of record-high levels of asylum claims in autumn 2015, the Department of Justice had proposed a temporary, three-year amendment to the Aliens Act aimed at reducing the numbers of asylum seekers. ${ }^{2}$ The Swedish government, a coalition of the Green Party and the Social Democrats, deemed the increase in the numbers of asylum seekers 'a serious threat to public order and internal security'. By adapting Swedish regulations to the EU minimum standard, it hoped to achieve a more equal distribution of asylum seekers across the EU and to give Sweden some 'breathing space' in accepting new refugees. ${ }^{3}$ The government's concerns were shared by a majority of the opposition parties in parliament. One explicit intention of the new regulations was 'to restrict the possibilities for getting residence permits also for children'. ${ }^{4}$

A couple of days earlier, newspapers had reported about a stormy, acrimonious consultation meeting at the Department of Justice. ${ }^{5}$ During the consultation period and the subsequent public debate, the draft proposals drew harsh criticism from almost every quarter. ${ }^{6}$ Universities, NGOs, churches,

${ }^{1}$ In Swedish: 'Utkast till lagrådsremiss: Begränsningar av möjligheten att få uppehållstillstånd i Sverige' (11 February 2016).

${ }^{2}$ The proposal to make changes to the Aliens Act was announced by the Swedish government at a press conference with Prime Minister Stefan Löfven and Deputy Prime Minister Åsa Romson on 24 November 2015. It was put forward as the government's response to the 'refugee crisis' that was unfolding in autumn 2015 . The proposal had been preceded by intense reporting and negotiations at the national and international levels about the EU's management of refugees. Sweden was thus only one among many European countries attempting to find political solutions to the increases in the numbers of refugees. In 2015 , a total number of 162,877 persons applied for asylum in Sweden. Of these, 70,384 were children, among whom 35,369 were unaccompanied minors ('Overview and time series', Migrationsverket, http://www.migrationsverket.se/English/About-the-Migration-Agency/Facts-and-statistics-/Statistics/Overview-and-time-series.html, accessed 5 December 2016).

${ }^{3}$ Kerstin Holm and Anna H Svensson, 'Regeringen: Ny lagstiftning för färre asylsökande', SVT Nyheter, 24 November 2015, http://www.svt.se/nyheter/inrikes/regeringen-utokade-id-kontroller-vid-gransen,_accessed 27 November 2016.

4 'Utkast till lagrådsremiss: Begränsningar av möjligheten att få uppehållstillstånd i Sverige', 36

5 Jens Kärrman, 'Tuffare asylregler får stark kritik', Dagens Nyheter, 3 March 2016, http://www.dn.se/nyheter/sverige/tuffare-asylregler-far-stark-kritik/, accessed 27 November 2016.

6 'Remiss av promemorian Begränsningar av möjligheten att få uppehållstillstånd i Sverige (utkast till lagrådsremiss)', http://www.regeringen.se/remisser/2016/02/remiss-av-begransningar-av-mojligheten-att-fa-uppehallstillstand-i-sverige/, accessed 27 November 2016. 
professional groups, the national child ombudsman and government agencies all argued that the draft was, among other things, poorly prepared, lacking impact assessments and lacking due consideration for the possible implications for human rights. One particular line of criticism was that there was no analysis of the impact of the law on children's rights, and that the law was in direct contravention of Sweden's commitments to the UN Convention on the Rights of the Child (UNCRC). The Swedish National Ombudsman for Children called the draft directly 'hostile to children' and along with others argued that, were it to be implemented, it would mark a departure from the policies on children's rights pursued by successive Swedish governments in previous decades and would violate certain provisions of the UNCRC namely, those relating to the best interests of the child (Article 3), the child's right to parents and family reunification (Articles 9, 10 and 18), the right to physical and psychological rehabilitation (Article 39) and the special attention paid in the convention to refugee children (Articles 22 and 39).

On 11 March, a day after the deadline for submissions of opinions regarding the temporary amendment of the Swedish asylum law, a government-appointed investigator delivered the national Children's Rights Inquiry report to the Swedish Government. ${ }^{8}$ The investigator had worked on the report for three years, charged with preparing for the incorporation of the UNCRC into Swedish law and making a number of legislative proposals to strengthen children's rights in a variety of different areas, including the asylum process. ${ }^{9}$ It was the culmination of nearly three decades of political and societal efforts to implement the UNCRC and to strengthen the enforcement of children's rights in Sweden. ${ }^{10}$

Shortly after this, however, some commentators highlighted the contrast between the aims of the Children's Rights Inquiry, on one hand, and the new law proposing to limit the possibilities for children to get residence permits, on the other. Criticism was levelled against the government for apparent

\footnotetext{
${ }^{7}$ Written Submission from the Swedish Child Ombudsperson regarding the government draft of referral to the Council of Legislation about 'Restriction on the ability to get residence permit in Sweden', 8 March 2016, http://www.regeringen.se/contentassets/cbebce43816043d6bf864dd0e076b722/14_barnombudsmannen.pdf, accessed 27 November 2016.

8 'The Child Rights Inquiry' (in Swedish: Barnrättighetsutredningen) Governmental Bill, SOU 2016:19.

${ }^{9}$ Since Sweden ratified the UNCRC in 1990, some of its individual provisions have been incorporated into Swedish legislation. In the Children's Rights Inquiry SOU 2016:19, the commission was, 'in addition to continued transformation, [to] provide the CRC the status of Swedish law' and 'to submit proposals for a law incorporation of the Convention and to highlight certain issues of legal and practical nature which arise at incorporation' (SOU 2016:19, 19).

${ }^{10}$ From the ratification of the UNCRC in the beginning of the 1990 s, there has been a series of policy and institutional measures relating to this implementation. The present government, which took office in 2014, declared it to be one of their top priorities. See e.g. SOU 2016:19 and 'Strategy to strengthen the rights of the child in Sweden' (Prop. 2009/2010:232).
} 
'double standards', for failing to live up to Sweden's international commitments and for departing from the consensus on 'children's rights politics'. ${ }^{11}$

What the consequences of the temporary amendment to the Aliens Act and the proposal to incorporate the UNCRC into Swedish law will be remains, at the time of writing, an open question. But what the 'refugee crisis' of autumn 2015 underlined, and those two days in March epitomised, were the disputes that arise out of a much older and more perennial matter: that of the rights of asylum-seeking children and how these have given rise to controversies around the universal rights of the child and the state regulation of immigration control.

\section{Children's rights and immigration control}

The UN Refugee Agency (UNHCR) reported at the end of 2015 that 65.3 million individuals had been forcibly displaced worldwide as a result of persecution, conflict, general violence or violations of human rights. ${ }^{12}$ Children below the age of eighteen constitute about fifty per cent of this number and about thirty per cent of the asylum seekers applying for residence permits in Europe. ${ }^{13}$ Although the number of forcibly displaced persons in 2015 was at its highest level since the Second World War, levels of global migration have been trending upwards for decades. ${ }^{14}$ In the wake of a steady flow of migrants attempting to cross borders and states' efforts to restrict immigration, ${ }^{15}$ media, NGOs, governments and scholars have been involved in reporting on and condemning what has been perceived as the recipient states' failure to

${ }^{11}$ Dane et al., 'Dubbla budskap om barns rättigheter', Dagens Nyheter, 10 March 2016, http://www.svd.se/dubbla-budskap-om-barns-rattigheter,accessed 27 November 2016; Bjereld et al., 'Föreslagna flyktinglagarna försämrar integrationen', Dagens Nyheter, 11 March 2016, http://www.dn.se/debatt/foreslagna-flyktinglagarna-forsamrar-integrationen/, accessed 27 November 2016; Viktor Banke, 'Regeringen har tappat känslan för barns rättigheter', Dagens Nyheter, 15 March 2016, http:/www.dn.se/kultur-noje/kulturdebatt/viktor-banke-regeringen-hartappat-kanslan-for-barns-rattigheter/, accessed 27 November 2016.

12 UNHCR, Global Trends: Forced Displacement in 2015, http://www.unhcr.org/statistics/unhcrstats/576408cd7/unhcr-global-trends-2015.html, accessed 27 November 2016.

${ }^{13}$ Ibid. See also 'Distribution by age of (non-EU) first time asylum applicants in the EU and EFTA member states, 2015', Eurostat, http://ec.europa.eu/eurostat/statistics-explained/index.php/File:Distribution_by_age_of_(non-EU)_first_time_asylum_applicants_in_the_EU_and_EFTA_Member_States,_2015_(\%C2\%B9)_(\%25)_YB16.png\#file, accessed 27 November 2016. In the thesis I use the term child in a general sense to refer to individuals under the age of 18 as stipulated in the UNCRC Art 1. I use it since this is a widely spread and accepted point of reference. This said, one essential purpose of the thesis is to problematize the category of children and to critically engage with different concepts of children and childhood and how these relate to issues of rights and asylum.

14 'Population Statistics', The UN Refugee Agency 2016, http://popstats.unhcr.org/en/overview, accessed 27 November 2016.

${ }^{15}$ Matthew J. Gibney, 'Is Deportation a Form of Forced Migration?', Refugee Survey Quarterly 32, No. 2 (2013): 116-29; Matthew J. Gibney and Randall Hansen, 'Deportation and the liberal state: the forcible return of asylum seekers and unlawful migrants in Canada, Germany and the United Kingdom', New Issues in Refugee Research, Working Paper No. 77 (2003). 
shoulder their obligations and respond to the urgent humanitarian needs of migrants, particularly migrant children. Reports have come in from around the world about: the 'child migrant crisis' at the southern border of the US, children crossing the Mediterranean sea, children in detention centres in Europe and on Nauru Islands outside Australia, children in danger of becoming victims of trafficking or at risk of deportation after long periods of residency. ${ }^{16}$

The public debate about the situation of child refugees in Sweden has for years been characterised by anti-deportation campaigns, protests and criticism of decisions to deny asylum-seeking children residence permits. Back in the mid-1990s, concerns were raised over the growing number of children being placed under extreme stress due to the risk of deportation, and since then the question of the rights of asylum-seeking children has continued to be a prominent issue in the media and the subject of heated public debate. ${ }^{17}$ Denials of children's asylum applications have been criticised - by the children themselves and by others - as inhumane, immoral and in contravention of Swedish commitments to the UNCRC. And the legal justifications provided by the Swedish migration agency and courts have been deemed unreasonable in public debates. Claims have been raised against state authorities for the rights of asylum-seeking children to residence on various grounds: ill health, the threat that deportation poses to the child's well-being and on the basis of the child having lived in Sweden for a long time. By contrast, mainstream, nationalist, right-wing and conservative parties have called for more restrictive immigration policies to limit the numbers of immigrants, including

${ }^{16}$ In recent years public and academic debates about children and asylum have been a recurrent theme in countries such as Norway, Denmark, the Netherlands, the UK, Australia and the US. For the UK, see Bridget Andersson, 'Where's the Harm in That? Immigration Enforcement, Trafficking and the Protection of Migrants' Rights', American Behavioral Scientist, 56, No. 9 (2012): 1241-57; Clotilde Giner, 'The Politics of Childhood and Asylum in the UK', Children and Society 21 (2007): 249-60. For the US: Jaqueline Bhabha, Child Migration and Human Rights in a Global Age, (Princeton, New Jersey: Princeton University Press, 2014); 'The Central American child and family and migrant crisis', VOX, http://www.vox.com/2014/6/16/5813482/the-child-migrant-crisis, accessed 27 November 2016. In Norway and Denmark: Karin Vitus and Hilde Lidén, 'The Status of the Asylum-seeking Child in Norway and Denmark: Comparing Discourses, Politics and Practices', Journal of Refugee Studies 23, No. 1 (2010): 62-81. In the Netherlands: Mariska Kromhout, 'Return of Separated Children: The Impact of Dutch Policies', International Migration 49, No. 5 (2009): 25-47; 'Defence for Children', Kinderpardon, http://www.defenceforchildren.nl/migratie, accessed 27 November 2016. In Australia: 'Children Out of Immigration Detention', http://www.chilout.org/, accessed 27 November 2016; Paul Farrell, Nick Evershed and Helen Davidson, 'The Nauru files: cache of 2,000 leaked reports reveal scale of abuse of children in Australian offshore detention', The Guardian, 10 August 2016, https://www.theguardian.com/australianews/2016/aug/10/the-nauru-files-2000-leaked-reports-reveal-scale-of-abuse-of-children-in-australian-offshore-detention, accessed 27 November 2016.

${ }^{17}$ Henry Ascher and Marita Eastmond, 'In the Best Interest of the Child? The Politics of Vulnerability and Negotiations for Asylum in Sweden', Journal of Ethnic and Migration Studies 37, No. 8 (2011): 1185-200. 
immigrant children, on the grounds of protecting the welfare state and national security. For their part, the Swedish migration agency and courts claim that they are simply following laws and procedures in accordance with the democratic institutions of the state.

The 'moral gap' between, on the one hand, the public calls for a more liberal migration policy regarding children, and on the other hand, the outcome of democratically enacted laws to control immigration, make visible a discrepancy between the meaning and use of the concept of the rights of asylum-seeking children at the level of legal decision making and the meanings and uses of children's rights in the claims of asylum-seeking children in the public sphere. The rights of asylum-seeking children have been analysed by children's rights and childhood scholars in previous research as will be outlined in chapter four of this thesis. Scholars like e.g. Bhahba, Smyth and Lundberg have primarily used international treaties such as the UNCRC, the European Convention on Human Rights (ECHR) or domestic law as their analytical and normative frameworks. ${ }^{18}$ Legal standards have been used to analyse and evaluate whether states' practices of immigration control are in compliance with the rights of asylum-seeking children according to what may be referred to as a top-down model or mainstreaming approach in research of children's rights. ${ }^{19}$ While there is no specific legal right of children to asylum in international law, the debate typically revolves around the fact that the granting of residence permits may be a means of protecting other basic rights of the child, such as a right to safety, health, family and participation, while a denial of asylum may be seen as a threat to these rights. ${ }^{20}$ Research adopting this approach has typically demonstrated states' failures

\footnotetext{
${ }^{18}$ See e.g. Jaqueline Bhabha, 'Arendt's Children: Do Today’s Migrant Children Have a Right to Have Rights?', Human Rights Quarterly 31, No. 2 (2009): 410-51; Giner, 'The Politics of Childhood'; Anna Lundberg, 'The Best Interests of the Child Principle in Swedish Asylum Cases: The Marginalization of Children's Rights', Journal of Human Rights Practice 3, No. 1 (2011): 49-70; Eva Nilsson, Barn i Rättens Gränsland: om barnperspektiv vid prövning om uppehållstillstånd (Uppsala: Iustus, 2007); Kirsten Sandberg, 'The Role of National Courts in Promoting Children's Rights', International Journal of Children's Rights 22 (2014): 1-20; Cynthia Smyth, 'The Common European Asylum System and the Rights of the Child: An Exploration of Meaning and Compliance', PhD Thesis, Leiden University, 2013; Wouter Vandenhole, 'Children's rights from a legal perspective: Children's rights law', in Routledge International Handbook of Children's Rights Studies, eds. Wouter Vandenhole et al. (Abingdon: Routledge, 2015), 27-42; Didier Reynaert, Maria Bouverne-De Bie and Stijn Vandevelde, 'Between "believers" and "opponents": Critical discussions on children's rights', International Journal of Children's Rights 20, No. 1 (2012): 155-68.

${ }^{19}$ Vandenhole, 'Children's rights from a legal perspective'.

${ }^{20}$ The term 'asylum' is in the thesis used in a general and historically familiar sense as the protection that a state grants on its territory to a person who comes to seek it. I do not refer to it in relation to any particular legal definition, provision or specific refugee status found in Swedish or international law. For a more thorough discussion about its historical origins and contemporary debates about the concept in international law see, María-Teresa Gil-Bazo, 'Asylum as a General Principle of International Law’, International Journal of Refugee Law 27, No. 1 (2015): 3-28.
} 
to protect the rights of asylum-seeking children, and the response has been to close the gap between the legal standard and the practice of immigration control by calling for 'more children's rights' through standard setting, implementation and monitoring.

The use of the UNCRC as an analytical framework to study children's rights has in recent years been the subject of various kinds of criticism. One line of critique, which is the focus of chapter two, has suggested that the academic study of children's rights has become too decontextualised and too preoccupied with a universal conception of rights and how these rights are implemented in practice. ${ }^{21}$ The particular social, economic and historical contexts are overlooked, and the differences between children as holders of rights and the various ways in which children's rights are given meaning and function in a specific context are neglected. Another line of critique, described in chapter three, points to the fact that the academic embrace of the UNCRC as an analytical framework has resulted in a lack of theorisation of the foundations of children's rights. ${ }^{22}$ The hegemonic status of the convention has hindered a critical scrutiny of the convention itself and theory-driven research into children's rights in general. In a sense, the convention has come to replace theory. ${ }^{23}$ When it comes to the rights of asylum-seeking children, after nearly three decades of implementation and mainstreaming of children's rights, as manifested in the UNCRC and in European law, the discrepancies between the meanings given to children's rights in the legal decision making, respectively in the claims of asylum seeking children in the public sphere remains, and seem to call for new ways of analysing the issue.

Against this backdrop, this thesis sets out to undertake an empirical examination of the controversies around children's rights and immigration control by studying the meaning and uses of children's rights in two particular settings: the Swedish Migration Court of Appeal, and Swedens largest morning paper Dagens Nyheter. These empirical studies will be a point of

\footnotetext{
${ }^{21}$ Sarada Balagopalan, Inhabiting Childhood: Children, Labour and Schooling in Postcolonial India (Basingstoke: Palgrave Macmillan, 2014); Karl Hanson and Olga Nieuwenhuys, Reconceptualizing Children's Rights in International Development: Living Rights, Social Justice, Translations (New York: Cambridge University Press, 2013); Manfred Liebel, Children's Rights from Below (New York: Palgrave Macmillan, 2012); Ann Quennerstedt, 'Children's Rights Research Moving into the Future - Challenges on the Way Forward', International Journal of Children's Rights 21 (2013): 233-47; Diddier Reynaert, Maria Bouverne-de Bie and Stijn Vandevelde, 'A review of children's rights literature since the adoption of the United Nations convention on the rights of the child", Childhood 16, No. 4 (2009): 518-34.

${ }^{22}$ Lucinda Ferguson, 'Not Merely Rights for Children But Children's Rights: The Theory Gap and the Assumption of the Importance of Children's Rights', International Journal of Children's Rights 21, No. 2 (2013): 177-208; Quennerstedt, 'Children's Rights Research Moving into the Future'; Reynaert et al. 'A review of children's rights literature' and 'Between "believers" and “opponents”'; John Tobin, 'Justifying Children's Rights', The International Journal of Children's Rights 21, No. 3 (2013): 395-441.

${ }^{23}$ Quennerstedt, 'Children's Rights Research Moving into the Future'.
} 
departure to engage theoretically in the rights of asylum seeking children in dialogue with contemporary political philosophy.

The political philosophical discussion about immigration policy, border control and the rights of migrants has been the subject of a growing amount of scholarly work. Political theorists have for decades puzzled over how to understand and respond to the ways in which the international state system handles global migration, citizenship and the human rights of migrants. ${ }^{24}$ They have been concerned with the issue of who should have the right to admission of what ethical, political or legal grounds, and what the responsibility of states are to admit immigrants. While the discretionary rights of sovereign states to control immigration and to exclude non-citizens have historically been central to the concept of the state in both political philosophy ${ }^{25}$ and in international law, ${ }^{26}$ they have faced challenges from a range of political and legal-theoretical positions in recent years. Scholars have argued in various ways for a reformation of the international community towards more porous borders or a more radical change towards open borders. ${ }^{27}$

As Benhabib observes, in our time of globalisation and transnational migration, citizenship can no longer be viewed as a unitary and stable given

\footnotetext{
${ }^{24}$ See for example Seyla Benhabib, The Rights of Others: Aliens Residents and Citizens (Cambridge: Cambridge University Press, 2004); Seyla Benhabib, Dignity in Adversity: Human Rights in Troubled Times (Cambridge: Polity Press, 2011); Joseph Carens, 'Aliens and citizens: The case for open borders', Review of Politics 49 (1987): 250-73; Joseph Carens, The Ethics of Immigration (Oxford: Oxford University Press, 2013); Hans Lindahl, Fault Lines of Globalization: Legal Order and the Politics of A-Legality (Oxford: Oxford University Press, 2013); Jonathan Seglow, 'The Ethics of Immigration', Political Studies Review 3, No. 3 (2005): 317-34; Veit Bader, 'The Ethics of Immigration', Constellations 12, No. 3 (2005): 331-61; Christopher H. Wellman and Philip Cole, Debating the Ethics of Immigration: Is there a right to exclude? (Oxford: Oxford University Press, 2011); Shelley Wilcox, 'The Open Borders Debate on Immigration', Philosophy Compass 4, No. 5 (2009): 813-21; Bas Schotl, On the Right of Exclusion: Law, Ethics and Immigration Policy (Abingdon: Routledge, 2012).

${ }^{25}$ See for example David Miller, 'In Defense of Nationality', Journal of Applied Philosophy 10, No. 1 (1993): 3-16; David Miller, 'On Nationality and Global Equality: A reply to Holtug', Ethics and Global Politics 4 (2011): 165-71; David Miller, Strangers in Our Midst; The Political Philosophy of Immigration (Harvard University Press 2016); Michael Walzer, Spheres of Justice: A Defense of Pluralism and Equality (New York: Basic Books, 1983); Wellman and Cole, Debating the Ethics of Immigration; Wilcox, 'The Open Borders Debate'.

${ }^{26}$ Marie-Benedicte Dembour, When Humans Become Migrants: Study of the European Court of Human rights with an Inter-American Counterpoint (Oxford: Oxford University Press, 2015); Benhabib, The Rights of Others; Linda Bosniak, The Citizen and the Alien: Dilemmas of Contemporary Membership (Princeton, New Jersey: Princeton University Press, 2008); Hans Lindahl, Fault Lines of Globalization; Bas Schotl, On the Right of Exclusion.

${ }^{27}$ Benhabib, The Rights of Others and Dignity in Adversity; Bosniak, The Citizen and the Alien; Carens, 'Aliens and citizens' and The Ethics of Immigration; Lindahl, Fault Lines of Globalization; Schotl, On the Right of Exclusion; Wellman and Cole, Debating the Ethics of Immigration; Wilcox, 'The Open Borders Debate'; Mattias Risse, 'Immigration, Ethics and the Capabilities Approach', Human Development Research Paper 2009/34, United Nations Development Program.
} 
'which bundle[s] together residence upon a single territory with the subjection of a single administration'. ${ }^{28}$ The 'disaggregation of citizenship' that 'permits individuals to develop and sustain multiple allegiances and networks across nation-state boundaries, in inter- as well as transnational contexts', she argues, is an inescapable aspect of globalisation. The disaggregation of citizenship challenges the conventional boundaries and meaning of political membership and thus the very normative foundations upon which modern democracies rest. Indeed, the rights claims of asylum-seeking children and the public contestations of current asylum laws seem to be illustrative examples of these implications of the disaggregation of citizenship.

However, the controversies over the rights of asylum-seeking children not only raise questions about immigration control and migrant rights in general (which have been dealt with extensively elsewhere), but also questions that are more specifically related to children and childhood. In the current international order, although being a child does not give you an absolute right to asylum, or imply an absolute duty on the part of a recipient state to grant you asylum, it typically opens up access to child-specific provisions in law and draws a moral attention that accords children a special priority over adults. ${ }^{29}$

What democratic states like Sweden seem to struggle with is how to handle those rights claims of asylum-seeking children that contest the law and the current state practice of immigration control. The discrepancy between legal reasoning and public reasoning about these matters makes evident, however, they deal with them in different ways and according to different logics, and this gives rise to a set of questions in need of further enquiry. What effects do the practices and systems of immigration control have on the meanings and uses of children's rights in the different settings in which they are in play? If children are entitled to universal rights in virtue of their being children, what does this entail for their special status in the asylum process? Which children should get rights to residence permits and which should not, and on what grounds? And if children are recognised as rights-

\footnotetext{
${ }^{28}$ Benhabib, The Rights of Others, 178.

${ }^{29}$ Even though an entitlement of the child could be established on the basis of, for instance, the UNCRC, determining who has the duty to protect such a right is another matter. In international law, it is primarily the duty of the state to protect the rights of its own citizens, and it becomes more problematic to determine the duties of states regarding the universal rights of noncitizen children. David Archard has discussed the theoretical problems associated with the assumption of maximising the best interests of the child. The interests of the child must always be put in relation to other interests, and it would, he argues, be implausible to claim that the state has a duty to act always and only in the best interests of the child without also considering other interests. David Archard, Children: Rights and Childhood, 3rd ed. (Abingdon: Routledge, 2015 ).
} 
bearing subjects in virtue of their status as human beings, rather than as children - making them more alike adults ${ }^{30}$ - what implications does this have for the status of children as political subjects in the context of immigration control? These considerations will in turn lead us to very fundamental questions about what it means to be a child and what children's rights are.

\section{Aim and outline of the thesis}

This thesis is in part an empirical examination of the meanings and uses of the rights of asylum-seeking children, what will be referred to as a sociopolitical practice of rights, in the legal, respectively, in the public reasoning about children and residence permits in the Swedish Migration Court of Appeal (MCA) and in Dagens Nybeter (DN). It is now about ten years since the MCA was introduced as the final instance in the new Swedish asylum process, but it is still the case that few studies of its jurisprudence and no comprehensive study of its decision making with respect to children and their rights have been conducted. As the final instance, the MCA and its judges play a critical role as interpreters of children's rights and in the development of domestic legal norms. To study the legal arguments of the MCA is thus ultimately a way of studying the actions of the Swedish state with regard to children's rights and of studying how children's rights figure in a domestic practice of immigration control. Dagens Nyheter is Sweden's largest morning paper, and it is a site in the public sphere in which different actors of Swedish society have deliberated and formulated rights claims against the state on behalf of asylum-seeking children. It is accordingly a setting that plays a critical role in reviewing state policy: it is a place in which public reasoning can contest and challenge the meanings and uses of the rights of asylum-seeking children found at a level of the Swedish Migration agency and the Swedish Migration Courts.

On another part, this thesis takes the empirical analysis of the MCA and $\mathrm{DN}$ as a starting point for a political-theoretical discussion about the conceptual and normative foundations of the rights of asylum-seeking children. For this discussion, I have chosen to engage with two contemporary philosophers, Martha Nussbaum (and her capability approach) and Seyla Benhabib (and her formulation of discourse ethics), to see whether they can offer a productive theoretical framework to examine the rights of asylum-seeking children. The capability approach Nussbaum has developed represents what may be referred to as an 'ethical entitlement' or an 'interest' theory of human rights with universal aspirations. This approach has been influential in a

\footnotetext{
${ }^{30}$ E. Verhellen and F. Spiesschaert (eds.), Ombudswork for children (Leuven: Acco Academic Publishing Company, 1989), 1.
} 
broad range of academic fields, but it has only to a limited extent been elaborated in the area of migration and children. Though Benhabib has not specifically addressed children, her writings on human rights in a global era, political membership, migration and justificatory processes in the public sphere offer another relevant starting point in this regard.

One aim of the thesis is to examine how the meaning and uses of children's rights and immigration control have developed through the jurisprudential decision making of the MCA and the ways in which legal decision making about the rights of asylum-seeking children have been contested by claims of asylum seeking children as formulated in the reporting of Dagens Nyheter. A second aim is to engage theoretically with the questions about the rights of asylum-seeking children in dialogue with contemporary political philosophy - and, more specifically, with the theories of Nussbaum and Benhabib.

I have formulated four broad questions for the thesis; these correspond to the four articles that constitute the bulk of the thesis.

1. How have the legal norms concerning children's rights in the asylum process developed in the MCA in recent years with regard to the meanings given to the Best Interest Principle (BIP) and how is this weighed against the state's interest in immigration control?

2. What are the arguments and claims put forward in DN, as a site within the public sphere, for children's rights to residence permits, and in what ways do these claims contest the legal norms and practices relating to children's rights in the asylum process?

3. Can Nussbaum's capability approach provide a useful theoretical framework for discussing children's rights to asylum?

4. Can Benhabib's approach to discourse ethics offer a productive theoretical and normative framework for analysing the rights claims of asylum-seeking children as they are formulated in the public sphere?

In this introductory chapter, I have described how in the wake of the migration of large populations of children across state borders, political controversies over the rights of asylum-seeking children and immigration control have given rise to a set of questions in need of further inquiry. Thereafter, I presented the overall aim and questions of the thesis.

In chapter two, I present the conceptual and theoretical framework that will play a crucial role in the empirical investigations in articles one and two 
in the thesis. It begins with an introduction to how the UNCRC and a topdown approach have emerged as analytical frameworks in the study of children's rights and how these have also been subject to the criticism for not enough take into account contextual factors relating to how the meanings of children's rights are shaped in practice. Building on the insights of this critique, I conclude the chapter by examining how the socio-political practice of rights can offer a vital analytical lens to the empirical study of children's rights.

In chapter three, I discuss children's rights as political philosophy and in doing so provide an important theoretical backdrop for the examination of the rights of asylum-seeking children in articles three and four. The chapter starts by describing a second line of critique of the top-down approach which highlights a need for further theorisation about children's rights - and turns to political philosophy in order to outline some of the dominant strands of thinking about children's rights in this field. It is in this context that I present Nussbaum's capability approach and Benhabib's discourse ethics, which I will then go on to analyse in articles three and four.

In chapter four, I focus on previous research more directly concerned with issues of migration and the rights of asylum-seeking children. I describe how there has been a childhood turn in migration research over the last few years, and I present studies from both an international perspective and from the Swedish context that are particularly relevant for the studies conducted in this thesis.

In chapter five, the materials and the methodological approach of the thesis are described. It starts out with a general description of my methodological approach which is followed by an account of materials and methodological considerations in relation to each study.

Chapter six consists of short summaries of the four articles, and in chapter seven I take the opportunity to summarise and synthesise some of the main conclusions of the four articles and discuss them together as a whole. The four articles themselves are attached as appendices. 


\section{CHILDREN'S RIGHTS AS A SOCIO-POLITICAL PRACTICE}

It seems hard today to speak about children and political change without using the language of children's rights. The idea of children's rights has come to influence a wide variety of areas in society that involve children, and they have become the key concepts for discussing issues such as poverty, war, family policy, health, education, migration and asylum. ${ }^{31}$ Ideas of children's rights are deployed in various spheres, from lawmaking, policy work and decision making in legal institutions, to political discourse, the work of governmental agencies and NGOs - not to mention in children's own political struggles. The significant spread of the language of children's rights indicates at one level an international consensus about the fact that children are entitled to a set of universal rights in virtue of their being children. This consensus is manifested in the nearly universal adoption of the UNCRC. At another level, when looking more closely at the different practices in which children's rights are deployed, it becomes evident that the meanings and uses of them vary with the societal and institutional contexts in which they operate.

Although the UNCRC has undoubtedly come to play a key role for scholars as a legal source, political point of reference and analytical framework, one purpose of this chapter is to show how the rights of children can be discussed also in other terms. In the chapter I will put forth the sociopolitical practice of children's rights as a theoretical and analytical lens for the empirical study of the rights of asylum-seeking children. In this context, in the legal argument of the MCA (article one) and in the rights claims of asylum-seeking children in DN (article two). The chapter divides into three parts. In the first part I begin with a description of how the UNCRC has become the cornerstone of children's rights over the last few decades. However, the increasing focus on standard setting, implementation and monitoring of the UNCRC - the top-down approach to children's rights - has been subject to critique. In the second part I describe how one line of critique suggests that, instead of starting out from children's rights as they are conceptualised and articulated in international treaties, research should rather focus on how rights are given meaning in particular contexts and as lived experiences for children. ${ }^{32}$ In the third part I present the socio-political practice of children's rights as a useful theoretical framework and vital alternative

\footnotetext{
${ }^{31}$ See e.g. Vandenhole et al., Routledge International Handbook of Children's Rights Studies; Hanson and Nieuwenhuys, Reconceptualizing Children's Rights; Archard, Children; Liebel, Children's Rights from Below; Bhabha, Child Migration and Human Rights.

${ }^{32}$ Liebel, Children's Rights from Below; Hanson and Nieuwenhuys, Reconceptualizing Children's Rights; Reynaert et al., 'Between "believers” and “opponents”'; Quennerstedt, 'Children's
} 
to the empirical study of the rights of asylum-seeking children in the MCA and in DN

\section{Children's rights and the UNCRC}

The UNCRC was adopted in 1989 and is today the most widely ratified UN treaty in history. It has become not only the dominant framework for the policy and practice of children's rights, but also for the academic study of children's rights. The implementation of the UNCRC and research about children's rights have in many respects become closely interlinked and have developed in tandem..$^{33}$ In the decades leading up to the UNCRC, scholars, politicians, advocates and civil society organisations demonstrated an increased interest in children's rights and a 'curiosity about the social position of the child' ${ }^{34}$ The interest in children, their rights and interests at the time of the adoption of the convention was certainly, from a historical perspective, not new (as is sometimes suggested). ${ }^{35}$ It can in fact be traced back at least to the end of the nineteenth century, after which time it gained ever-

Rights Research Moving into the Future'; Pamela Reynolds et al., 'Refractions of children's rights in development practice: a view from anthropology - Introduction', Childhood 13, No. 3 (2006): 291-302.

${ }^{33}$ Michael Freeman (ed.), Children's Rights: Progress and Perspectives - Essays from the International Journal of Children's Rights (Leiden: Martinnus Nijhoff Publishers, 2011); Michael Freeman (ed.), Children's Rights, 2 vols. (Aldershot, UK, and Burlington, VT: Ashgate, 2004).

${ }^{34}$ Verhellen and Spiesschaert, Ombudswork for children, is a particularly interesting historical record of the scholarly debates that were taking place at the time of the emergence of the UNCRC. See also Cynthia Rae Margolin, 'Salvation versus Liberation: The Movement for Children's Rights in a Historical Context', Social Problems 25, No. 4 (1978): 441-52; Zoe Moody, 'Transnational treaties on children's rights: norm building and circulation in the twentieth century', Paedagogica Historica 50, Nos. 1-2 (2014): 151-64.

${ }^{35}$ See e.g. Jean Zermatten, 'Best Interests of the Child', in Child-friendly Justice: A Quarter of a Century of the UN Convention on the Rights of the Child, eds. Said Mahmoudi et al. (Leiden: Brill Nijhoff, 2015), 30-42. Zermatten represents a line of thinking that regards the UNCRC as 'inventing' children's rights or the unique status of children. This position is undermined, however, by historical research that shows how the idea of children's rights can be traced back further in time - Moody suggests at least to the end of the nineteenth century. See e.g. Bengt Sandin, 'History of Children's Well-Being', in Handbook of Child Well-Being: Theories, methods and policies in global perspective, eds. Asher Ben-Arieh et al. (Dordrecht: Springer, 2013), 31-86; Bengt Sandin, 'Children and the Swedish Welfare State: From Different to Similar', in Reinventing Childhood after World War II, eds. Paula S. Fass and Michael Grossberg (Philadelphia: University of Pennsylvania Press, 2012), 110-38; Dominique Marshall, 'Reconstruction Politics, the Canadian Welfare State and the Ambiguity of Children's Rights, 1940-1950', in Uncertain Horizons. Canadians and their World in 1945, ed. Greg Donaghy (Ottawa: Canadian Committee for the History of the Second World War, 1996), 261-83; Moody, 'Transnational treaties'; Paula Fass, 'A Historical Context for the United Nations Convention on the Rights of the Child', Annals of the American Academy of Political and Social Science 633 (2011): 17-29; Hugh Cunningham, Children and Childhood in Western Society since 1500, 2nd ed. (Harlow: Pearson Education, 2005), 41. 
greater international currency - manifested, for instance, in the Geneva Declaration of 1924 and the UN Declaration on the Rights of the Child of $1959 .{ }^{36}$

In the 1970s, there was clearly an increase in scholarly interest in children's rights. ${ }^{37}$ Not unlike today, the debate was torn between, on the one hand, those who regarded children as different from adults, with a special need to be protected by society - through salvation - and, on the other hand, those who attributed to children agency and viewed them as rights-bearing individuals whose interests were to be advanced in the same way as those of adults, through liberation. ${ }^{38}$ The movement for the protection of children had during the nineteenth and early twentieth centuries been concerned with saving children 'at risk' because of delinquency, being orphaned, inadequate schooling, harsh labour conditions, war, poverty, and living on the streets. ${ }^{39}$ From the 1970s onwards, however, there was a growing and increasingly dominant tendency to describe and interpret the lives of children in terms of rights and to stress that children are similar to adults - and so to seek their emancipation rather than their salvation. ${ }^{40}$

In his introductory remarks to the first International Congress on Ombudswork for Children in Ghent in December 1987, a conference of around thirty scholars from various disciplines discussing the issue of children's rights, Professor E. Verhellens characterised the contemporary interest in children and childhood by stating that attention should no longer only be paid to the position of 'children-as-children', but simultaneously 'and in a more substantial way to the position of "children-as-human beings". ${ }^{41}$ The idea that was gaining social and political ground at this time was that children above all are human beings and not just 'human-beings-to-be'.

Today, almost three decades later, the UNCRC stands out as the most influential of the different legal and political documents that regulate children's rights at a global level. Children's rights are often simply equated with the UNCRC. The UNCRC has been ratified by 195 states, making it the

\footnotetext{
${ }^{36}$ Moody, 'Transnational treaties'; Fass, 'A Historical Context'; Sandin, 'History of Children's Well-Being'; Margolin, 'Salvation versus Liberation'.

${ }^{37}$ Bruce C. Hafen, 'Children's Liberation and the New Egalitarianism: Some Reservations About Abandoning Youth to Their "Rights"', BYU Law Review 605, No. 3 (1976): 605-58; Margolin, 'Salvation versus Liberation'; Richard Farson, Birthrights: a bill of rights for children (Harmondsworth: Penguin Books, 1974); John Holt, Escape from Childhood: the needs and rights of children (Oxford: Oxford University Press, 1973); Francis Schrag, 'Rights over children', The Journal of Value Inquiry 7, No. 2 (1973): 96-105; Michael S. Wald, 'Children's Rights: A Framework for Analysis', UCD Law Review 12 (1979): 255-82.

${ }^{38}$ Margolin, 'Salvation versus Liberation'.

${ }^{39}$ Sandin, 'History of Children's Well-Being'; Anthony Platt, 'The Rise of the Child-Saving Movement: A Study in Social Policy and Correctional Reform', Annals of the American Academy of Political and Social Science 381 (1969): 21-38.

${ }^{40}$ Sandin, 'History of Children's Well-Being'; Margolin, 'Salvation versus Liberation'.

${ }^{41}$ Verhellen and Spiesschaert, Ombudswork for children, 1.
} 
most ratified human rights treaty of all time. ${ }^{42}$ In addition, three optional protocols have been adopted: one on the Involvement of Children in Armed Conflict (OPAC); one on the Sale of Children, Child Prostitution and Child Pornography (OPSC); and one regarding Communication Procedures (CP) that allow children or their representatives to file individual complaints about violations of the rights of a child. ${ }^{43}$ The UNCRC can be broken down into three main parts. The first gives a general definition of what a child is, sets out general principles and a more detailed list of specific rights and obligations; the second part deals with the UNCRC's main monitoring body, the Committee on the Rights of the Child; and the third enumerates some final provisions about the ratification procedure, amendments, reservations, etc. ${ }^{44}$ It covers civil and political rights as well as economic, social and cultural rights. Some of the articles are commonly understood to be guiding principles for the interpretation of other articles and have thus become more frequently used than others: ${ }^{45}$ for instance, Article 2, the non-discrimination principle; ${ }^{46}$ Article 3, relating to the best interests of the child; ${ }^{47}$ Article 6, the right to life; ${ }^{48}$ and Article 12, the right be heard. ${ }^{49}$

A growing amount of research takes the UNCRC as its point of departure and analyses the different articles of the convention and their meanings in particular areas such as health, participation, abuse and neglect, education, migration, etc., identifying areas in which the UNCRC has not been

${ }^{42}$ Vandenhole, 'Children's rights from a legal perspective'.

${ }^{43}$ Optional Protocol to the Convention on the Rights of the Child on the involvement of children in armed conflict (OPAC), A/RES/54/263, http://www.ohchr.org/EN/ProfessionalInterest/Pages/OPACCRC.aspx, accessed November 27; Optional Protocol to the Convention on the Rights of the Child on the sale of children, child prostitution and child pornography (OPSC); A/RES/54/263, http://www.ohchr.org/EN/ProfessionalInterest/Pages/OPSCCRC.aspx, accessed November 27 2016; Optional Protocol to the Convention on the Rights of the Child on a communications procedure (CP), A/RES/66/138, http://www.ohchr.org/EN/ProfessionalInterest/Pages/OPICCRC.aspx, accessed November 272016.

${ }^{44}$ Vandenhole, 'Children's rights from a legal perspective'; UNCRC.

${ }^{45}$ Michael Freeman, 'The future of children's rights', Children \& Society 14 (2000): 277-93.

${ }^{46}$ UNCRC Article 2:1, 'States Parties shall respect and ensure the rights set forth in the present Convention to each child within their jurisdiction without discrimination of any kind, irrespective of the child's or his or her parent's or legal guardian's race, colour, sex, language, religion, political or other opinion, national, ethnic or social origin, property, disability, birth or other status'.

${ }^{47}$ UNCRC Article 3:1, 'In all actions concerning children, whether undertaken by public or private social welfare institutions, courts of law, administrative authorities or legislative bodies, the best interests of the child shall be a primary consideration'.

${ }^{48}$ UNCRC Article 6, ' 1 . States Parties recognize that every child has the inherent right to life. 2. States Parties shall ensure to the maximum extent possible the survival and development of the child'.

${ }^{49}$ UNCRC Article 12:1, 'States Parties shall assure to the child who is capable of forming his or her own views the right to express those views freely in all matters affecting the child, the views of the child being given due weight in accordance with the age and maturity of the child'. 
fully implemented. ${ }^{50}$ Such research focuses on the UNCRC or other treaties on children's rights and asks whether specific societal practices involving children are in compliance with the standards enshrined in these laws and policies. This line of research typically rests on the assumption that children's rights are an outcome of legal negotiations that took place during the decades leading up to the UNCRC, which were then codified in the convention and subsequent legal instruments (e.g. additional protocols and general comments) and institutions (e.g. the Committee on the Rights of the Child and Children's Ombudspersons), and which should now be implemented. ${ }^{51}$ The scholarly focus on standard setting, implementation and monitoring of the UNCRC follows a more general trend of 'mainstreaming' and 'manegerialism' of human rights in international politics that have been actively pursued for many years by NGOs, interest groups and, for example, the Committee on the Rights of the Child. ${ }^{52}$

This approach, the top-down approach to children's rights, has in recent years been the subject of various kinds of criticism. As mentioned above, critics have suggested that the academic study of children's rights using the UNCRC as an analytical framework has neglected the significance of the different contexts in which children's rights operate and the effect these contexts have on their meaning; further, this approach has been criticised for preventing a critical scrutiny of children's rights and the convention itself and resulted in a lack of theorisation of children's rights themselves. ${ }^{53}$ The first line of critique will be discussed in the sections below before I present my alternative of analysing children's rights as a socio-political practice. The second line of critique - about the lack of theorisation - will be developed in chapter 3 .

${ }^{50}$ Freeman, Children's Rights and Children's Rights: Progress and Perspectives; Said Mahmoudi et al., Child-friendly Justice; Quennerstedt, 'Children's Rights Research Moving into the Future'; Reynaert et al., 'A review of children's rights literature' and 'Between "believers" and "opponents"'; Vandenhole, 'Children's rights from a legal perspective'.

${ }^{51}$ Vandenhole, 'Children's rights from a legal perspective'; Heather Montgomery, 'Children's Rights', in Oxford Bibliographies: Childhood Studies, ed. Heather Montgomery (Oxford: Oxford University Press, 2015); Mahmoudi et al., Child-friendly Justice; Sara Dillon, International Children's Rights (Durham, NC: Carolina Academic Press 2010); Freeman, Children's Rights.

${ }_{52}$ Martti Koskenniemi, 'The politics of international law - 20 years later', The European Journal of International Law 20, No. 1 (2009). According to Koskenniemi, the mainstreaming of human rights means that institutions increasingly make use of the concept of human rights in official documents, which in turn opens up the possibility for human rights experts to pronounce upon whether particular rights are being upheld or violated in an apparently neutral language one which, according Koskenniemi, is always nevertheless covertly political.

${ }^{53}$ Ferguson, 'Not Merely Rights'; Hanson and Nieuwenhuys, Reconceptualizing Children's Rights; Quennerstedt,'Children's Rights Research Moving into the Future'; Reynaert et al., 'A review of children's rights literature' and 'Between "believers" and "opponents"; Tobin, 'Justifying Children's Rights'. 


\section{Children's rights: from top-down to bottom-up}

The critique of the top-down approach for being too decontextualised argues that it does not properly take into account the ways in which the meanings and uses of children's rights are shaped through context and in the everyday lives of children. ${ }^{54}$ Critics have noted how the frequent use of the UNCRC as the ultimate definition of children's rights and as the prime frame of reference for research has meant that particular social, economic and historical contexts, and children themselves as holders of rights, tend to be overlooked. Instead of starting out from children's rights as they are conceptualised and articulated in international treaties, these critics focus on how the exercise and enjoyment of rights in various contexts gives them meaning as lived experiences. Liebel argues that the central question for research into children's rights is: what is the relevance of these rights to the children themselves, and how do they make use of them in their current and future lives? ${ }^{55}$ He claims that the technical debate about the effectiveness of implementation crowds out analysis of these sorts of questions. To examine how children's rights become relevant to children, they must be 'conceptualized in a context-specific way and give answers to children's life experiences and differences'. ${ }^{56}$

In their introduction to a special issue of Childhood devoted to children's rights in development practice, Reynold et al. propose that anthropological perspectives can be particularly valuable in examining the everyday lives of children and practices of children's rights. ${ }^{57}$ By starting out from the experiences of children, it becomes clear that the implementation of the UNCRC may, in practice, clash with priorities set by children themselves. Some of the more controversial examples in this context are participation in armed conflict, sex work or living on the streets as representing conscious decisions made by children in dire circumstances. ${ }^{58}$ Children may in this way act to build a better future for themselves and their families in ways that fly in the face of the UNCRC's core assumption that the state or parents are best placed to take responsibility for children's protection. ${ }^{59}$ This highlights some of the challenges and radical consequences of acknowledging children's subjectivity.

\footnotetext{
${ }^{54}$ Hanson and Nieuwenhuys, Reconceptualizing Children's Rights; Solveig Hägglund, Debora Harcourt, 'Turning the UNCRC upside down: a bottom-up perspective on chuldren's rights', International Journal of Early Years Education 21, No 4 (2013): 286-299;Liebel, Children's Rights from Below; Quennerstedt, 'Children's Rights Research Moving into the Future'; Reynaert et al., 'Between "believers" and "opponents”'; Reynolds et al., 'Refractions of children's rights'.

${ }^{55}$ Liebel, Children's Rights from Below, 2.

${ }^{56}$ Ibid.

${ }^{57}$ Reynolds et al., 'Refractions of children's rights'.

${ }^{58}$ Ibid., 292.

${ }^{59}$ Ibid.; Manfred Liebel, A Will of their Own: Cross-Cultural Perspectives on Working Children (London: Zed Books, 2004).
} 
Nieuwenhuys and Hanson add the concept of what they call 'translations' to this approach to children's rights as lived experiences. ${ }^{60}$ With this concept they mean to emphasise the fact that the law always represents a translation of real-world ideas of right and wrong that are based on lived experiences. They seek thus to capture the 'tensions at work between global and local formulations of children's rights'. Children's rights are not merely the products of deliberations and international agreements; they are ideas that already exist before they are translated into legal principles. A translation of children's rights thus becomes a multiple-way process in which topdown and bottom-up interpretations interact that 'transforms the power relations of all actors involved'. ${ }^{61}$ These ideas are exemplified by children's struggles to have a voice on issues in which their interest appears to conflict with international policy and NGO-driven agendas. One example often referred to in this regard is the political organisation and struggle of children for a right to decent working conditions, in contrast to an international agenda of banning child labour. ${ }^{62}$ These kinds of encounters between children and other actors, between the global and the local, which transform and give new meaning to children's rights, are what Hanson and Nieuwenhuys seek to highlight with the concept of translation.

Seeing children's rights from a bottom-up perspective - as lived, contextspecific experiences - consequently implies a challenge to the implementation of universal rights as enshrined in the UNCRC from 'above'. The approach sees an emancipatory potential in children's rights: the potential to address power imbalances, injustices and to help children in their political struggles to define their own rights. The acknowledgment of children's rights as tied to contexts and as given meaning by particular practices provides an important backdrop to the next section.

\section{The socio-political practice of children's rights}

As noted in the introduction, a central purpose of this thesis is to undertake an empirical examination of how norms about the rights of asylum-seeking children and immigration control have been established and contested throughout the years in the Migration Court of Appeal and in Dagens Nyheter. To address this aim, the empirical examinations of children's rights in these two settings have been conducted with a particular focus on how children's rights and interests are given meaning and are used and on how different actors are engaged in the establishment and contestation and the

\footnotetext{
${ }^{60}$ Hanson and Nieuwenhuys, Reconceptualizing Children's Rights, 16.

${ }^{61}$ Ibid, 21.

${ }^{62}$ Ibid.; Liebel, A Will of their Own and Children's Rights from Below.
} 
claiming and denial of rights through what I refer to as a socio-political practice of children's rights. ${ }^{63}$ In this respect, I share with the bottom-up approach the call for an acknowledgement of context in the study of children's rights. But while a bottom-up approach to children's rights as the 'lived experiences of children' usually draws on the insights of anthropology and sociology in the everyday life of children and on methods of interviewing and observation, this thesis draws rather on traditions of political science and philosophy and on methods of textual analysis of legal decision making and public debate.

For this purpose, two scholars are of particular importance. The first is Ruth Lister, who has been engaged with conceptual and theoretical issues relating to children and rights. Lister sees rights as something more than just legal statuses. Looking at citizenship and rights as legal statuses means being primarily concerned with the legal and formal relationship between the individual and the state. By contrast, a socio-political practice of rights focuses on the social processes through which individuals and social groups engage in claiming, expanding or losing rights internally or externally vis-à-vis the political community. ${ }^{64}$ In her theoretical enquiries into children's rights and citizenship, she follows a more general contemporary trend among scholars to construct rights and citizenship in terms of a dynamic relationship between citizenship as a legal status and citizenship as a socio-political practice. ${ }^{65}$ Lister finds this approach particularly fruitful from the perspective of children, for their legal and political status is somewhat ambiguous: they are 'not yet fully citizen[s]' ${ }^{66}$ For example, children who are citizens of their country are entitled to some rights - e.g. education, health, welfare benefits, etc. - while not being entitled to other rights. For instance, they do not have a right to vote or hold public office. Key to a socio-political practice of rights, according Lister, is the question of 'human agency, which provides the link between conceptions of citizenship as an active, participatory practice and as a set of rights, which are the object of struggle'. ${ }^{67}$ While Lister's discussion addresses the rights of children largely in the context of citizenship and the

${ }^{63}$ Lindahl, Fault Lines of Globalization; Ruth Lister, 'Why Citizenship: where, when and how children?' Theoretical Inquiries in Law 8, No. 2 (2007): 693-718; Mehmoona Moosa-Mitha, 'A Difference-Centred Alternative to Theorization of Children's Citizenship Rights', Citizenship Studies 9, No. 4 (2005): 369-88; Nancy Fraser, 'Rethinking the Public Sphere: A Contribution to the Critique of Actually Existing Democracy', Social Text 25/26 (1990): 56-80.

${ }^{64}$ See also Engin F. Isin and Bryan S. Turner, 'Citizenship Studies: An Introduction', in Handbook of Citizenship Studies, eds. Engin F. Isin and Bryan S. Turner (London: Sage, 2002), 1-10; Saskia Sassen, 'Towards Post-National and Denationalized Citizenship', in Isin and Turner, Handbook of Citizenship Studies, 277-92.

${ }^{65}$ Ibid.; Lister, 'Why Citizenship', 695.

${ }^{66}$ Ibid.; see also Kirsi Paulina Kallio and Jouni Häkli, 'Are there politics in childhood?', Space \& Polity 15, No. 1 (2011): 21-34; Sana Nakata, Childhood Citizenship, Governance and Policy: The Politics of Becoming Adult (Abingdon: Routledge, 2015); John Wall, 'Can democracy represent children? Towards a politics of difference', Childhood 19, No. 1 (2012): 86-100.

${ }^{67}$ Lister, 'Why Citizenship', 695. 
nation state, I find her approach useful also in the context of children, rights and global migration and with regard to non-citizens: non-citizens, like children, make claims from the margins or from outside the political community.

Another important scholar is Hans Lindahl, who, in light of globalisation, has developed a political and legal theory that places social interaction and behaviour at its centre and suggests that claims of rights and 'strange' behaviour (an event or behaviour that has no place within the currently existing legal order) can 'disrupt' and challenge the normative boundaries of legal orders and can contest what and who ought to be included in law. ${ }^{68} \mathrm{His}$ starting point is that no legal order is conceivable unless it is bounded subjectively (who), materially (what), spatially (where) and temporally (when). ${ }^{69}$ These dimensions make up a single order that both joins and separates what is to be included and what is to be excluded in the order from a first person plural perspective $-\mathrm{a}$ ' $w e$ '. ${ }^{70}$ Lindahl thus acknowledges a normative potential in legally unorderable social interactions and behaviour: they are ways of questioning the boundaries of legal orders from the margins or outside which, in turn, can open up ways of drawing the boundaries differently. ${ }^{71}$

To study the rights of asylum seeking children along this line, imply that focus is put on how claims of asylum seeking children in different ways challenge the current boundaries of the law by finding their normative source in social interaction and public claim making also outside established legal and political institutions. In line with Lindahl's legal theory, studying the claims of asylum-seeking children as a socio-political practice of rights appears to be a promising strategy since their status is somewhat ambiguous: they are effectively non-citizens, making claims from the margins or from outside the political community, ${ }^{72}$ and they are children, 'citizens in the making' with limited political and legal rights. ${ }^{73}$

\section{Situating socio-political practice in human rights thinking}

The idea of rights as socio-political practices shares similarities with some other approaches to human rights found in contemporary scholarship. ${ }^{74} \mathrm{Ma}-$

\footnotetext{
${ }^{68}$ Lindahl, Fault Lines of Globalization.

${ }^{69}$ Ibid., $18 \mathrm{ff}$.

${ }^{70}$ Ibid., 40.

${ }^{71}$ Ibid., 3, 37.

${ }^{72}$ Benhabib, The Rights of Others; Bosniak, The Citizen and the Alien.

${ }^{73}$ Lister, 'Why Citizenship'; Wall, 'Can democracy represent children?'; Nakata, Childhood Citizenship.

${ }^{74}$ For further discussions and comparisons of different traditions of thinking about human rights, see Charles Beitz, The Idea of Human Rights (Oxford: Oxford University Press, 2009); Rowan Cruft, S. Matthew Liao and Massimo Renzo (eds.), Philosophical foundations of human rights (Oxford: Oxford University Press, 2015); Marie-Benedicte Dembour, 'What Are Human Rights? Four Schools of Thought', Human Rights Quarterly 32, No. 1 (2010): 1-20; Samuel Moyn, The
} 
rie-Bénédicte Dembour has identified four different schools of thought relating to human rights. ${ }^{75}$ The most common approach she calls the 'natural school'. On this view, human rights are conceptualised as something absolute that individuals possess simply in virtue of being human beings. ${ }^{76}$ However, this orthodox view of rights has, she notes, increasingly moved towards a more deliberative school of thought, which conceives of rights as political values that liberal societies have chosen to adopt through agreement; on this view, then, rights are limited to those that are actually manifested in law. ${ }^{77}$ The protest school is concerned first and foremost with redressing injustice and regards human rights as the articulation of claims and aspirations made by or on behalf of the unprivileged and oppressed; on this view, human rights thus contest the status quo in favour of the oppressed. According to the discourse school, finally, human rights exist because people talk about them. They have become a powerful language in which to express political claims; this language can be used for various purposes, not all of which are emancipatory.

In light of this categorisation of approaches to human rights, we can say that the socio-political practice of rights approach appears not really to resemble the natural school, but it does share an interest in social processes and agreement with the deliberative school - although without limiting itself to conventional political and legal institutions. The socio-political practice approach to children's rights is perhaps closest to the protest and the discourse schools. The protest school emphasises claims and aspirations that challenge the status quo, and, as we will see in the second article of this thesis, the rights claims in DN do just this. The discourse school acknowledges the way in which human rights can be used in different ways and for different purposes.

\section{The socio-political practice of rights in The Migration Court of Appeal and Dagens Nyheter}

Approaching children's rights as a socio-political practice has consequences for how children's rights are studied in the settings of the MCA (article one) and in DN (article two). In the study of the legal arguments of the MCA, particular attention is paid to the meanings given to children's rights - in this case, the best interest of the child (the BIP) - and how it is weighed against

Last Utopia: Human Rights in History (Cambridge, MA: Harvard University Press 2010); Samuel Moyn, Human Rights and the Uses of History (London: Verso Books, 2014); Neil Stammers, Human Rights and Social Movements (London: Pluto Press, 2009).

${ }^{75}$ Dembour, 'What Are Human Rights?', 2 ff.

${ }^{76}$ Cruft, Liao and Renzo (eds.), Philosophical foundations of human rights, 2.

${ }^{77}$ Ibid, 2ff, Dembour, 'What Are Human Rights?', 2 ff. 
state interests in immigration control. The study does not focus on the legality or correctness of the court's decision making in relation to some specific legal standard of children's rights. Instead, it focuses on how children's rights are used and given normative force in the legal arguments in this particular practice of immigration control and how different actors, given the institutional premises, are engaged in the establishment and contestation of legal norms about the rights of asylum-seeking children. A socio-political practice of rights rejects the idea that a word or concept has an inherent meaning independent of the surrounding expressions, and holds instead that the meaning of a concept is given by the use of it in relation to other expressions and contextual circumstances. ${ }^{78}$ Consequently, this kind of analysis contrasts with approaches that attempt to 'fix' the (universal) meaning of children's rights and its central concepts in abstraction by finding 'the correct intention' in the legislative history or by founding the meaning on any sort of metaphysics.

In the examination of DN, I will show how the rights of asylum-seeking children are asserted in contexts outside the established political and legal institutions. They are asserted by children themselves and by other actors working on their behalf in the public sphere, often contesting the legal authority of the state and the status quo of the currently existing legal and political order. ${ }^{79}$ In this sense, the studies of the MCA and DN demonstrate how a socio-political practice of children's rights follows different logics, which are closely connected to the institutional setting in which children's rights are in play.

To sum up, in this chapter I have described how the UNCRC over the last few decades has come to exercise a significant influence on the academic discussion of children's rights. I have also described the way in which the increasing focus on standard setting, implementation and monitoring of the UNCRC, the top-down approach to children's rights, has come in for criticism. One line of critique has been concerned with the lack of contextualisation, and it argues that studies of children's rights should pay attention to the meaning and uses given to rights in particular contexts and through the lived experiences of children. Finally, I have said that instead of studying the rights of asylum-seeking children by using international agreements such as the UNCRC, or the rights of children as enshrined in domestic law, as the chief analytical framework, this thesis uses the socio-political practice of rights as a theoretical and analytical lens through which to view the meanings and uses of children's rights and through which to understand how different

\footnotetext{
${ }^{78}$ Martti Koskenniemi, From Apology to Utopia: The Structure of International Legal Argument (Cambridge: Cambridge University Press, 2005), 6-7; Isabella Fairclough and Norman Fairclough, Political Discourse Analysis: A Method for Advanced Students (Abingdon: Routledge, 2012), 22.

${ }^{79}$ Fraser, 'Rethinking the Public Sphere', 57
} 
actors are engaged in the establishment, contestation, claiming and denial of rights in the settings of the MCA and DN. 


\section{CHILDREN'S RIGHTS AS POLITICAL PHILOSOPHY}

In this chapter, I consider a second line of critique of the top-down approach to children's rights: that it has led to a lack of theorisation of children's rights in the contemporary scholarship. I will start by outlining this critique and, in the second section, turn to political philosophy in order to highlight some of the theoretical discussions about children's rights that have been taking place in this field, with the aim of laying the groundwork for a theoretical discussion of the rights of asylum-seeking children. This will be followed by a presentation of two contemporary theories of human rights: Martha Nussbaum's capability approach and Seyla Benhabib's discourse ethics (which are the objects of my theoretical analyses in articles three and four).

\section{The UNCRC and lack of theorisation}

The second line of criticism of a top-down approach focuses on the lack of theorisation about children's rights and the UNCRC itself. Quennerstedt notes how the contemporary work on standard setting, implementation and monitoring of the UNCRC has resulted in a situation in which 'the Convention is frequently used as (the ultimate) definition of children's rights, and often constitutes the only frame of reference for the research undertaken; it motivates the research questions, is the tool used to analyze data and is the structure against which the results of a study is mirrored'. ${ }^{80}$ Vandenhole observes in similar way that a lot of the legal approaches to children's rights have been occupied with what he calls the 'implementation gap': the problem of the lack of implementation of existing legal standards with respect to children's rights. ${ }^{81}$ These legal approaches seem to assume, according Vandenhole, that 'relevant standards exist for each children's rights issue, that the meaning of these standards is clear, and that these standards are able to satisfactorily address the issue at stake. The standards themselves are therefore seldom called into question'. ${ }^{82}$

In her article on the twenty-fifth anniversary of the adoption of the UNCRC, Quennerstedt suggests that the consensus around the UNCRC as a definition of children's rights is one of the most urgent concerns for future

\footnotetext{
${ }^{80}$ Quennerstedt, 'Children's Rights Research Moving into the Future', 240.

${ }^{81}$ Vandenhole, 'Children's rights from a legal perspective', 27.

82 Ibid.
} 
research in this area. ${ }^{83}$ The hegemonic status of the convention, she argues, has hindered theory-driven research and blurred the important distinction between advocating for children's rights and the analytical aspects of children's rights. To some extent, she states, the UNCRC can be said to have replaced theory; this indicates, then, a need for further theorisation of children's rights. But, as I will show in the next section, while a theory gap has been identified in the dominant approach to children's rights research, theoretical debates about children's rights have nonetheless taken place, if to a limited extent, in moral and political philosophy.

\section{Political philosophy and the nature of childhood}

Though the history of philosophy offers us examples of discussions about the nature of childhood and the social and political status of children, the child as a specific object of study has in the mainstream of philosophy been a marginal figure and seldom dealt with in any systematic or comprehensive way. ${ }^{84}$ From the latter part of the twentieth century into the beginning of the twenty-first century, however, there has been growing interest among philosophers in the moral and political status of children, specifically in relation to the rights of the child. ${ }^{85}$ I will start by describing some of the most commonly held views and conceptions of children in contemporary philosophy, before going on to present the dominant theoretical approaches to children's rights in contemporary political philosophy.

One commonly held view in contemporary political philosophy is that the child by definition is non-political, since the child is to be understood as different from an adult - as 'not yet' an adult or citizen. ${ }^{86} \mathrm{~A}$ prevalent idea is that the child lacks the competence, capacity or autonomy to be a politically

\footnotetext{
${ }^{83}$ Quennerstedt, 'Children's Rights Research Moving into the Future', 244.

${ }^{84}$ David Archard and Colin Macleod (eds.), The Moral and Political Status of Children (Oxford: Oxford University Press, 2002); Archard, Children; Samantha Brennan and Robert Noggle, 'John Rawls's Children', in The Philosopher's Child: Critical Perspectives in the Western Tradition, eds. Gareth B. Matthews and Susan M. Turner (Rochester, NY: University of Rochester Press, 1998), 203-32; Matthews and Turner, The Philosopher's Child; Francis Schrag, 'The Child's Status in the Democratic State', Political Theory 3, No. 4 (1975): 441-57; John Wall, 'Human Rights in Light of Childhood', International Journal of Children's Rights 16 (2008): 523-43; John Wall, Ethics in Light of Childhood (Washington DC: Georgetown University Press, 2010).

${ }^{85}$ In the 1970 s we can note a particular attention to children as rights-bearing subjects in a growing literature about, and movement for, children's rights (e.g. Margolin, 'Salvation versus Liberation'; Holt, Escape from Childhood; Farson, Birthrights; Schrag, 'The Child's Status'). After some years of relative silence, the beginning of the twenty-first century saw renewed interest in children's rights (e.g. Archard, Children; Archard and Macleod, The Moral and Political Status of Children; Matthews and Turner, The Philosopher's Child; Wall, Ethics in Light of Childhood).

${ }^{86}$ Archard, Children, 41 ff.; Kallio and Mäkli, 'Are there politics in childhood?'; Nakata, Childhood Citizenship.
} 
active and participating citizen in the proper sense of the word. Children are considered 'unfinished' or 'undeveloped' human beings ${ }^{87}$ or 'citizens in the making' ${ }^{88}$ who cannot or ought not to have access to the political sphere of decision making or be the bearers of rights in any traditional sense. The political sphere belongs to adults. Consequently, if children's interests are to be protected - whether these relate to welfare, education, health or security they must be represented by adults, such as their parents, guardians, representatives of the state or other actors. ${ }^{89}$ This understanding of the child can be found, in slightly differing ways, in a line of classical philosophical works from Plato, Locke and Kant to thinkers of the twentieth century like T.H. Marshall, John Rawls and Robert Dahl, to name just a few. ${ }^{90}$

The non-political status of the child is often made clear by the fact that children are excluded from full citizenship or the political spheres and are portrayed as fundamentally different from adults without further explanation or enquiry. ${ }^{91}$ Hannah Arendt argued, for instance, that children should be sheltered by their parents from political life and that childhood belongs to the private sphere, in which children prepare themselves for entering the public. ${ }^{92}$ In other cases, an explicit distinction is drawn between children and

${ }^{87}$ Tamar Schapiro, 'What is a child?', Ethics 109 (1999): 715-38; Archard, Children, 41 ff.; Wall, Ethics in Light of Childhood.

${ }^{88}$ T.H. Marshall, Citizenship and Social Class: and Other Essays (Cambridge: Cambridge University Press, 1950).

${ }^{89}$ Schapiro, 'What is a child?', 720; Brennan and Noggle, 'John Rawls's Children'; Wall, Ethics in Light of Childhood.

${ }^{90}$ Matthews and Turner, The Philosopher's Child. At this point I put this broad range of thinkers together in order to demonstrate a general pattern of how children have been conceptualised within political philosophy. I am well aware that a more thorough analysis of their accounts of children would offer more nuances, but that unfortunately cannot be covered within the scope of this brief overview. To mention some classical accounts, Plato, for instance, advances the idea that children enter the world as irrational animals in need of rigorous ethical training. In a famous passage he depicts the boy as the 'craftiest, most mischievous and unruliest of brutes' (Plato, The Laws, in the collected dialogues of Plato), whose brutish nature must be tamed if the child is to be a good citizen. John Locke's view of the child and childhood is somewhat more positive in the sense that, like Aristotle, he sees in childhood the beginnings of the unfolding of natural reason (John Locke, Two Treatises of Government (Cambridge: Cambridge University Press, 1988), 126-33, 138 ff.). According to Locke, the child is not an unruly animal; rather, the child's mind is 'white paper' (tabula rasa) in need of experience and education if the child is to increase his or her rational freedom and develop towards enlightened social reason (Locke, Essay concerning human understanding' (book 2, chapter 1, section 2) and Wall, Ethics in Light of Childhood, 115). Without the ability to exercise rational freedom, however, children cannot possess 'natural rights' or be full citizens, since they lack the capacities necessary to exercise social freedom without doing themselves or others harm.

${ }^{91}$ T.H. Marshall regards the child in a similar way as Locke, as a citizen in the making. In John Rawls's Theory of Justice, children are represented by their parents in the 'original position' according to the 'head of family' thesis (see Brennan and Noggle, 'John Rawls's Children'). In Robert Dahl's influential democratic theory, he asserts that democracy belongs only to adults, without further explanation.

${ }^{92}$ Hannah Arendt, 'Reflections on Little Rock', Dissent 6, No. 1 (1959): 55; Sana Nakata, 'Elizabeth Eckford's Appearance at Little Rock: The Possibility of Children's Political Agency', Politics 28, No. 1 (2008): 19-25. 
adults: children by definition lack effective authority over themselves; they lack their own will and 'alien' forces determine what they do or say. ${ }^{93}$ As Schapiro writes, 'some differences ought to count, such as the difference between adults and children. It is only by turning our philosophical attention to these differences that we can learn how to act responsibly in spite of them'. ${ }^{94}$ In a similar vein, James Griffin argues that the incapacities of children and infants disqualify them as rights bearers; but this does not mean, he says, that we therefore have less weighty obligations towards them than we do towards other adults. ${ }^{95}$

Whereas this conventional view regarded children as non-political, scholarship has increasingly come to engage with the political agency of children and the politics of childhood. ${ }^{96}$ Instead of excluding children from citizenship and politics per se, the focus has been to acknowledge the politics of childhood and to investigate the child as a political actor and rights claimant. This line of research has, on one hand, pointed to the fact that children have more competencies, capacities, autonomy, and are better equipped for political participation, than commonly has been acknowledged. ${ }^{97}$ On the other hand, scholars have claimed that the specificity of children and young people's political agencies, roles and action in 'everyday life' may provide an

${ }^{93}$ Schapiro, 'What is a child?'

${ }^{94}$ Ibid., 738.

${ }^{95}$ James Griffin, On Human Rights (Oxford: Oxford University Press, 2008), 33, 83 ff.

${ }^{96}$ Kirsi Paulina Kallio, 'Performative bodies, tactical agents and political selves: rethinking the political geographies of childhood', Space \& Polity 11, No. 2 (2007): 121-36; Kirsi Paulina Kallio and Jouni Häkli, 'Children and Young People's Politics in Everyday Life', Space \& Polity 17, No. 1 (2013): 1-16; Nakata, 'Elizabeth Eckford's Appearance' and Childhood Citizenship; Jacob Lind, 'The duality of children's political agency in deportability', Politics, Prepublished 6 September 2016, DOI: 10.1177/0263395716665391; Lister, 'Why Citizenship'; Moosa-Mitha, 'A Difference-Centred Alternative'; Wall, Ethics in Light of Childhood and 'Can democracy represent children?; John Wall, 'Why Children and Youth Should Have the Right to Vote: An Argument for Proxy-Claim Suffrage', Children, Youth and Environments 24, No. 1 (2014): 10823 . The interest in the political agency of children can historically be seen in light of an increased attention paid to children as rights bearers in the latter part of the twentieth century and a questioning of the previously taken for granted child-adult dichotomy. Allison James, Chris Jenks and Alan Prout (Theorizing childhood (Cambridge: Polity Press, 1998)) argue that a paradigmatic shift took place in the beginning of the 1980s in which childhood itself was made the locus of concern rather than its being subsumed under other topics like the family or schooling. They describe a shift away from a biological reduction of childhood and stages of development, a pre-social child, towards a sociocultural understanding of childhood as historically, socially and contextually bounded and thus a view of children as possessing agency. Sandin similarly notes how the concept of childhood has transformed throughout history from an emphasis on their difference (särart) and the romantic conception of the child as possessing specific rights in the beginning of the twentieth century to a conception of childhood as more similar to adulthood - and the consequent granting of agency and rights to children on a par with those granted to adults (Sandin 2003 p. 236).

${ }^{97}$ Archard and Macleod, The Moral and Political Status of Children; Samantha Brennan, 'Children's Choices or Children's Interests: Which Do Their Rights Protect?', in Archard and Macleod, The Moral and Political Status of Children, 53-68; Holt, Escape from Childhood; Wall, 'Why Children and Youth Should Have the Right to Vote'. 
alternative to traditional political institutions and to traditional ways of conceiving of the political..$^{98}$ Commentators pursuing these lines of argument generally want to question traditional assumptions about the concept of the child and the concept of the political.

\section{Children's rights in political philosophy}

In the following I will outline two of the dominant theories of children's rights: interest theories of rights and will (or choice) theories of rights. I will then present a third theoretical approach that has recently been put forward as an alternative: the difference-oriented theory of children's rights (as I shall call it). These three theories have been developed particularly in relation to children and childhood but also intersect with philosophical discussion about rights more generally. ${ }^{99}$ The interest theory of rights focuses primarily on the protection of rights that are based on fundamental interests, where these interests are seen as not dependent upon the capacities or autonomy of the rights-bearing subject. ${ }^{100}$ Since it seems plausible that children have fundamental interests, one can argue on this basis that children should be understood as having rights - to be secured by the state or by other actors - to, for instance, food, housing, health, education, care or development. ${ }^{101}$ These interests are not determined by the choices of the child but are instead derived from, for example, the 'nature' of the child or of the human being or from the choices of their parents, guardians or other adults in the political community that have the capacities to make autonomous and rational choices about what is in the interest of the child. John Tobin is one recent proponent of an interest theory of rights for children. He sets out an interest theory of children's rights grounded in the international consensus about the UNCRC. ${ }^{102}$ The consensus is, in turn, based on 'a conception of dignity where all human beings, including children, have unique value and a conception of

${ }^{98}$ Kirsi Paulina Kallio and Jouni Häkli, 'Children and Young People's Politics in Everyday Life', Space \& Polity 17, No. 1 (2013): 1-16; Nakata, 'Elizabeth Eckford's Appearance' and Childhood Citizenship.

${ }^{99}$ Archard, Children, 58.

${ }^{100}$ Ibid., 59 ff.; Neil MacCormick, 'Children's Rights: a Test Case for Theories of Right', in Legal Right and Social Democracy: Essays in Legal and Political Philosophy (Oxford: Oxford University Press, 1984); Joseph Raz, The Morality of Freedom (Oxford: Oxford University Press, 1986), 165 ff.; Martha Nussbaum and Rosalind Dixon, 'Children's Rights and a Capabilities Approach: The Question of Special Priority', Cornell Law Review 97 (2012): 549-94.

101 Archard, Children; Nussbaum and Dixon, 'Children's Rights'.

102 Tobin, 'Justifying Children's Rights'. Tobin claims his social interest theory can be distinguished from theories of urgent interest (Beitz, The Idea of Human Rights) or those of basic interests (Kristen Hessler and Allen Buchanan, 'Specifying the Content of the Human Right to Health Care', in Medicine and Social Justice: Essays on the Distribution of Health Care, eds. Rosamond Rhodes, Margaret P. Battin and Anita Silvers (Oxford: Oxford University Press, 2002), 84-101). 
children as being vulnerable relative to adults yet possessing an evolving capacity for agency and autonomy'. But the UNCRC and its foundation in dignity is not sufficient to provide a settled catalogue of rights and interests; instead it offers the potential, Tobin argues, for a dynamic and inclusive development of children's rights that is contingent on 'anthropological realities' and 'contemporary political conditions'. ${ }^{103}$

In contrast, according to the will theory of rights, a right is a protected exercise of choice. ${ }^{104}$ To have a right is to have the power to enforce or waive the duty of others to respect one's decision with respect to a particular matter. For these theories, autonomy and the capacity to exercise rights are conditions of being entitled to them. Some defenders of a will theory of rights have argued that since children lack these capacities, they are simply not entitled to these kinds of rights. ${ }^{105}$ James Griffin grounds his account of human rights in 'normative agency', in our personhood and capacity to be 'self-deciders', with the implication being that since infants are not normative agents in this sense they cannot be entitled to human rights. ${ }^{106}$ This does not mean, according Griffin, that adults do not have moral obligations towards children - on the contrary, they do. But on his account they do not have them because children have human rights. ${ }^{107}$ Another way of approaching the rights of the child according to a will theory might be to concede that infants or younger children lack the capacity to exercise rights but to insist that this does not imply that children do not have rights. Instead, the rights can be exercised by proxy through representatives such as parents or guardians. ${ }^{108}$ Such a representative would 'choose for the children as the children would choose if they were capable of choosing for themselves'. ${ }^{109}$ The exercise of rights by proxy would only take place in the period during which children are incapable of making competent choices by themselves. Understood in this way, the will theory does not seem so far from the interest theory. Samantha Brennan suggests that it is possible to combine interest- and will-based theo-

103 Tobin, 'Justifying Children's Rights', 434.

${ }^{104}$ Griffin, On Human Rights; H.L.A. Hart, Essays on Bentham: Studies in Jurisprudence and Political Theory (Oxford: Clarendon Press, 1982), 183; Hillel Steiner, An Essay on Rights (Oxford: Blackwell, 1994).

${ }^{105}$ Griffin, On Human Rights, 83 ff.; Harry Brighouse, 'What Rights (If Any) Do Children Have?', in Archard and Macleod, The Moral and Political Status of Children, $31 \mathrm{ff} . ;$ Onora O’Neill, 'Children's Rights and Children's Lives' Ethics 98, No. 3 (1988): 463.

${ }^{106}$ Griffin, On Human Rights, 33, 83 ff.

107 James Griffin, 'Do children have rights?', in Archard and Macleod, The Moral and Political Status of Children, 19-30; Griffin, On Human Rights, 83. Similarly, O'Neill rejects the idea that talk of 'rights' is the proper way to address moral queries about children and holds that that talk of 'obligations' and 'duties' provides a more constructive way (O'Neill, 'Children's Rights').

${ }^{108}$ Archard, Children, 59; Wall, 'Why Children and Youth Should Have the Right to Vote'.

${ }^{109}$ Archard, Children, 59; Wall, 'Why Children and Youth Should Have the Right to Vote' 
ries and defends a gradualist model according to which the grounds for attributing rights to children change in accordance with the gradual development of the child's autonomy. ${ }^{110}$

The difference-oriented theory of children's rights is a third alternative proposed by theorists such as John Wall, Ruth Lister and Mehmoona Moosa-Mitha. ${ }^{111}$ They contend that childhood itself poses fundamental and critical questions about how the idea of rights and human rights are constructed within a liberal tradition that has largely centred on autonomous decision making. ${ }^{112}$ Their alternative difference-centred or difference-oriented conception of children's rights 'addresses children's agency and acknowledges their presences as participating subjects in the multiple relationships in which they interact'. ${ }^{113}$ Moosa-Mitha contrasts a difference-centred theory with the classical liberal accounts of rights put forward by, for instance, Nozick, Rawls and Dworkin, which conceptualise rights primarily in terms of individual ownership or entitlement, with 'the self' understood as the rights-bearing subject vis-à-vis the state. ${ }^{114}$ In its emphasis on the relational aspects of childhood and on membership in society, she notes some commonalities between the difference-centred approach and the communitarian approaches to rights represented by, for example, Kymlicka and Taylor. ${ }^{115}$ But she stresses that a difference-centred approach to membership is a broader approach which focuses on the ways in which membership is shaped by patterns of exclusion and inclusion of participation in the mainstream culture and society. Wall calls for a shift from seeing children as requiring the same rights as adults to seeing children as fundamentally transforming what is meant by human rights as such. ${ }^{116}$ His approach to the human rights of children takes as its starting point post-modern ethics and the theories of philosophers such as Emmanuel Levinas and Paul Ricoeur. From them he borrows the idea of moral responsibility to 'the other', by which he means 'the marginal and the dispossessed, those who are "othered" by being robbed of freedom and agency'. ${ }^{117}$ Although children may not be autonomous or free in the same sense as adults, they are just as 'other', diverse, and plural as

\footnotetext{
${ }^{110}$ Brennan, 'Children's Choices'.

${ }^{111}$ Moosa-Mitha, 'A Difference-Centred Alternative'; Lister 'Why Citizenship'; Wall, 'Human Rights' and Ethics in Light of Childhood.

112 Ibid.

${ }^{113}$ Moosa-Mitha, 'A Difference-Centred Alternative', 370.

${ }^{114}$ Ibid. Ronald Dworkin, Taking Rights Seriously (Cambridge, MA: Harvard University Press, 1977); Robert Nozick, Anarchy, State and Utopia (New York: Basic Books, 1974); John Rawls, A Theory of Justice (Cambridge, MA: Harvard University Press, 1971).

${ }^{115}$ In her discussion she refers to Will Kymlicka, Multicultural Citizenship: A Liberal Theory of Minority Rights (Oxford: Clarendon Press, 1995); Charles Taylor, Multiculturalism and the Politics of Recognition (Princeton: Princeton University Press, 1994).

116 Wall, 'Human Rights', 542.

117 Ibid., 537.
} 
everyone else. If rights are grounded in free, equal or autonomous individuality, 'children will be pressed to the outer edges of the social circle'. For this reason, Wall suggests, we must see rights as grounded instead in the responsibility to construct ever more other-inclusive societies.

\section{Children's rights theory and the rights of asylum-seeking children}

Despite all the work done by political philosophers on these theories of children's rights, they have not been discussed specifically in relation to the issue of migration. The theories have primarily been developed or applied in a context of the nation state or the family and so in relation to, for example, political participation, legal procedures, medical decision making, family relations, education, child bearing, child rearing and care, etc. In the same way as traditional theories of the rights of 'citizens' in the more general philosophical debate have been criticised and revised in order to account for the fact of global migration, we might also discuss and revise the traditional theories of children's rights for this same oversight. ${ }^{118}$ As Benhabib notes, citizenship can no longer be viewed as a stable given; it is developed through multiple allegiances and networks across nation-state boundaries. Moreover, in the case of child migration, the growing numbers of unaccompanied asylum-seeking minors and new forms of transnational family relations makes clear that children and their rights must also be thought of outside the context of the 'traditional' family. These insights are important to keep in mind as I go on, in what follows, to tie the three theories to the project of this thesis and briefly introduce Nussbaum's capability approach and Benhabib's discourse ethics.

Before I described how the interest theory, as put forward by e.g. Tobin, has been used as a general theoretical basis for the UNCRC. ${ }^{119}$ In a similar vein, David Archard has linked the philosophical analysis of children's interests with the application of the BIP (Article 3 of the UNCRC), in the context of medical decision making and child custody cases. ${ }^{120}$ Nussbaum's capability approach, which to some extent may be regarded as an entitlement or interest theory of rights, has increasingly been examined by childhood scholars

\footnotetext{
${ }^{118}$ E.g. Benhabib, The Rights of Others and Dignity in Adversity; Carens, The Ethics of Immigration; Lindahl, Fault Lines of Globalization; Schotl, On the Right of Exclusion; Bosniak, The Citizen and the Alien.

${ }^{119}$ Tobin, 'Justifying Children's Rights'.

${ }^{120}$ David Archard and Marit Skivenes, 'Balancing a Child's Best Interests and a Child's Views', International Journal of Children's Rights 17 (2009): 1-21.
} 
working in areas such as education, poverty, political participation and organised leisure time. ${ }^{121}$ Still, as far as I can see, this theory has not been applied to the issue of asylum-seeking children. Although Nussbaum herself, as I will explain below, has only offered a minimal discussion of the rights of children, her interest in global justice and the universal aspirations of her theory appear to offer us an interesting starting point for discussing the rights of asylum-seeking children.

The will theory of rights has been used as an argument for rejecting the idea that children have rights in any fundamental sense and for the claim that their welfare and needs are better protected in terms of obligations. ${ }^{122}$ But the will theory of rights (as well as the interest theory of rights) has also been used to argue for the expansion of children's democratic participation, through proxy rights and representation, and so for seeing children (or at least those with the requisite capacities) as members of society in a fuller sense. ${ }^{123}$

The difference-oriented theory, just like the will theory, has been used as a theoretical foundation for discussions of expanded democratic participation and the greater social and political inclusion of children ${ }^{124}$ As I mentioned in the discussion of the socio-political practice of rights, a differenceoriented theory appears to be particularly useful when it comes to children and non-citizens since they can be understood as making claims from the margins or from outside the political community. As will be explained below, this way of thinking about rights, which seeks to include in dialogue those 'others' who have previously been excluded, also has much in common with Benhabib's discourse ethics. Though Benhabib has not discussed the rights of children in any systematic way, her interest in global migration and the human rights of the 'other' makes her theory particularly relevant in this context.

As mentioned in the introduction, despite almost three decades of implementation strategies for the UNCRC, simply carrying on with more of the same does not seem to be a promising strategy, nor does it fully grasp what is at stake in the controversies around the rights of asylum-seeking children and the right of states to control immigration. This thesis has set out to discuss alternative conceptual and normative foundations for children's rights

\footnotetext{
${ }^{121}$ Mario Biggeri, Jérôme Ballet and Flavio Comim (eds.), Children and the Capability Approach (Basingstoke: Palgrave Macmillan, 2011); Daniel Stoecklin and Jean-Michel Bonvin (eds.), Children's rights and the capability approach: challenges and prospects (Berlin: Springer, 2014); Gottfried Schweiger, Gunter Graf and Mar Cabezas (eds.), 'Special Issue: Justice and Disadvantages during Childhood: What Does the Capability Approach Have to Offer?', Ethical Perspectives 23, No. 1 (2016): 101-30.

122 Griffin, On Human Rights.

${ }^{123}$ Wall, 'Why Children and Youth Should Have the Right to Vote'; Archard, Children, 59.

124 Wall, 'Can democracy represent children?' and 'Why Children and Youth Should Have the Right to Vote'; Moosa-Mitha, 'A Difference-Centred Alternative'; Lister, 'Why Citizenship'.
} 
as a way of approaching a number of complex issues related to citizenship, migrant rights and immigration control with particular relevance to children and childhood. The question is, then, which alternative conceptual and normative foundation for children's rights can move the analysis forward about what is empirically and theoretically at stake? The rights of asylum seeking children expose some of the general challenges that have confronted the international community for decades in the wake of global migration and globalisation, but they also raise questions of particular relevance to children and childhood. If children are entitled to universal rights in virtue of their being children, what would this entail for their particular status in the asylum process? Which child should get a right to a residence permit and which should not, and on what grounds? And what implications does it have if children are recognised as rights-bearing subjects on a par with adults, not only as 'children-as-children' but also as 'children-as-human beings'? Below I will briefly present the two theories that I have selected as potentially relevant for addressing these challenges.

\section{Martha Nussbaum's capability approach}

The capability approach has been influential in a broad range of academic fields ever since it was developed by Amartya Sen and Martha Nussbaum a couple of decades ago. ${ }^{125}$ According to Nussbaum, this approach can be defined as 'an approach to comparative quality-of-life assessment and to theorizing about basic social justice'. ${ }^{126}$ A central feature is the freedom to choose; so, when measuring or evaluating a functioning, it is essential to account for the freedom to choose. As Nussbaum puts it: 'The crucial good societies should be promoting for their people is a set of opportunities or substantial freedoms, which people then may or may not exercise in action: the choice is theirs. It thus commits itself to respect for people's powers of self-definition'. ${ }^{127}$

A fundamental element of Nussbaum's account is a ten-point list of central capabilities that a decent political order must secure for all citizens in virtue of their being humans. By emphasising the universal entitlements of human beings and attributing to the world community a general duty to realise them, her approach clearly reveals its universal aspirations. Though

\footnotetext{
${ }^{125}$ Ingrid Robeyn and Harry Brighouse (eds.), Measuring Justice: Primary Goods and Capabilities (Cambridge: Cambridge University Press, 2010); Ingrid Robeyn, 'The Capability Approach', Stanford Encyclopedia of Philosophy (Winter 2016 Edition), Edward N. Zalta (ed.), forthcoming URL = https://plato.stanford.edu/archives/win2016/entries/capability-approach/.

${ }^{126}$ Martha Nussbaum, Frontiers of Justice: disability, nationality, species membership (Cambridge, MA: Harvard University Press, 2007), 18.

${ }^{127}$ Ibid.
} 
Nussbaum does not discuss the rights of children in much detail, ${ }^{128}$ the capability approach has lately become influential in the field of children's rights and childhood studies as a theoretical framework for discussing issues like education, poverty, political participation, etc. ${ }^{129}$ It has served as an instrument for measuring, comparing and conceptualising well-being as a normative framework for social justice and as a way of operationalising formal entitlements such as children's rights. ${ }^{130}$ However, with only a few exceptions it has not been discussed in relation to global migration nor in relation specifically to the rights of asylum-seeking children. ${ }^{131}$

\section{Seyla Benhabib's discourse ethics}

Benhabib's discourse ethics ${ }^{132}$ can be placed within a tradition of 'discourse ethical' thinking about human rights. ${ }^{133}$ These approaches share with the 'political conceptions' of human rights ${ }^{134} \mathrm{a}$ view of human rights according to which they are not 'natural' or 'foundational' rights derived from a pre-social or pre-political order and belonging to humans as such. ${ }^{135}$ Instead, these approaches claim that the conceptual and normative foundations of rights are to be sought within moral and political discourse among reasonable persons. ${ }^{136}$ Benhabib's political theory about human rights and migration has grown out of an insight that citizenship can no longer be viewed as a unitary and stable given 'which bundle[s] together residence upon a single territory with the subjection of a single administration' and that the 'disaggregation

${ }^{128}$ Nussbaum and Dixon, 'Children's Rights'.

${ }^{129}$ Biggeri, Ballet and Comim, Children and the Capability Approach; Stoecklin and Bonvin, Children's rights.

${ }^{130}$ Stoecklin and Bonvin, Children's rights.

${ }^{131}$ Ahn Avllsup, Religious Ethics and Migration: Doing Justice to Undocumented Workers (Abingdon: Routledge, 2014), 73; Risse, 'Immigration'.

${ }^{132}$ E.g. Seyla Benhabib, Situating the Self: gender, community, and postmodernism in contemporary ethics (New York: Routledge, 1992); Seyla Benhabib, 'Reason-Giving and Rights-Bearing: Constructing the Subject of Rights', Constellations 20, No. 1 (2013): 38-50; Benhabib, The Rights of Others and Dignity in Adversity.

${ }^{133}$ Benhabib, Situating the Self, The Rights of Others, Dignity in Adversity and 'Reason-Giving'; Rainer Forst, 'The Basic Right to Justification: Toward a Constructivist Conception of Human Rights', Ethics 120 (2010): 711-40; Kenneth Baynes, 'Discourse ethics and the political conception of human rights', Ethics \& Global Politics 2, No. 1, (2009): 1-21.

${ }^{134}$ Beitz, The Idea of Human Rights; Joshua Cohen, 'Minimalism about Human Rights: The Most We Can Hope For', The Journal of Political Philosophy 12 (2004): 190-213; John Rawls, The Law of Peoples with 'The Idea of Public Reason Revisited' (Cambridge, MA: Harvard University Press, 2001).

${ }^{135}$ Cruft, Liao and Renzo, Philosophical foundations, 2; James Nickel, Making Sense of Human Rights, (Oxford: Blackwell, 2007), 7 ff.

${ }^{136}$ E.g. Beitz, The Idea of Human Rights; Cruft, Liao and Renzo, Philosophical foundations; Forst, 'The Basic Right'; Rainer Forst, Justification and Critique: Towards a Critical Theory of Politics (London: Polity, 2013); Benhabib, 'Reason-Giving'; John Rawls, 'The Idea of Public Reason Revisited', The University of Chicago Law Review 64, No. 3 (1997): 765-807. 
of citizenship' is an inescapable aspect of globalisation that 'permits individuals to develop and sustain multiple allegiances and networks across nationstate boundaries, in inter- as well as transnational contexts'. ${ }^{137}$

This view of human rights as based in moral and political discourse fits well with the idea, introduced in chapter two, of children's rights as a sociopolitical practice. In this respect, foundational interest or will theories that draw their normative foundations from a more traditional moral theory or from some kind of metaphysics appear to sit less well with the empirical aims of this thesis. Furthermore, Benhabib's interest in the public sphere and the potential it has for discussions of democratic legitimacy and human rights outside of the law and the authority of the state makes her theory a productive alternative to the mainstream, top-down model of children's rights. Another factor that makes her theory relevant is that she has spent considerable time developing a theoretical justification strategy for human rights, especially in relation to the international state system, political membership and movement across borders. ${ }^{138}$ It is a theory that is oriented to difference and the rights of 'others', and in this sense it appears to be more suitable than more traditional liberal approaches to rights, which are more tightly bound to citizenship of the nation state. But even though Benhabib has focused on the rights of non-citizens, the justification of human rights and the role of the public sphere in general, it is evident that children, and specifically asylum-seeking children, do not figure centrally in her analysis or in those of others political conceptions or discourse ethical accounts to human rights. ${ }^{139}$ Again, though, despite the fact that she - like the majority of contemporary political theorists - has not specifically addressed children's rights and children as rights-bearing subjects, ${ }^{140}$ her writings on human rights in a global era, political membership, migration and justificatory processes in the public sphere appear to offer a relevant starting point for thinking about these issues. ${ }^{141}$

To summarise, I started out by describing some of the criticism that has been levelled against the use of the UNCRC as an analytical framework - in short, the criticism is that this focus has meant a lack of theorisation of children's rights themselves. Following this, I presented some dominant theories

\footnotetext{
${ }^{137}$ Benhabib, The Rights of Others, 178.

${ }^{138}$ In setting out Benhabib's views, I make use of Benhabib's Situating the Self, The Rights of Others, Dignity in adversity and 'Reason-Giving'.

${ }^{139}$ For example, in the writings of Rawls, Benhabib, Beitz and Forst, children are mentioned on a few occasions, but they are never made the subject of a thorough discussion.

${ }^{140}$ Scant attention has been paid by political philosophers to children in migration, and these issues have seldom been treated in any systematic fashion (Jonathan Josefsson, 'Children as Moral Subjects in Ethics of Immigration', Proceedings from the $49^{\text {th }}$ Societas Ethica Annual Conference, 23-26 August 2012, 147-160, http://www.ep.liu.se/ecp/097/013/ecp12097013.pdf, accessed 5 December 2016).

${ }^{141}$ Benhabib Situating the Self, The Rights of Others, Dignity in Adversity and 'Reason-Giving'.
} 
of children's rights in contemporary political philosophy in order to see what theoretical resources this field might offer, particularly in relation to the rights of asylum-seeking children. At the end of the chapter, I briefly presented the theories of Nussbaum and Benhabib, which will be the object of my analyses in articles one and two. In the preceding chapters, I have described the political controversies over children's rights and immigration control as significant challenges for the international community and for Western democracies, and I have outlined children's rights as a socio-political practice and children's rights as political philosophy as providing my conceptual and theoretical framework for thinking through these challenges. Before I present the material and method of the thesis, I will in the next chapter present the current state of research into migration and the rights of asylumseeking children. 


\section{MIGRATION AND THE RIGHTS OF ASYLUM- SEEKING CHILDREN}

In this chapter, I focus on the rights of children in the context of migration and asylum. Chapters two and three dealt with how scholars have approached children's rights empirically and theoretically in different ways, and they presented the socio-political practice of rights and the theories of Nussbaum and Benhabib as important theoretical and analytical starting points for the thesis. This chapter is concerned more specifically with the contemporary state of research about the rights of asylum-seeking children. In the first section, I will describe what I call a childhood turn in recent migration research: a growing interest in children's roles, experiences and perspectives in transnational migration. In the second section, I focus particularly on studies of children, rights and asylum seeking both from an international perspective and in the Swedish context.

\section{A childhood turn in migration research}

As the American migration and human rights scholar Jaqueline Bhabha notes, the 1990s saw a growing interest among governments in offering new policies and responses with respect to refugee children. ${ }^{142}$ Up until that point, migrant children had been rather considered the appendages or possessions of others, like parents and families. Those without families became the responsibility of diasporic community organisations from their countries of origin. ${ }^{143}$ Bhabha identifies two factors that were key to this transformation. The first was population driven: a growing number of unaccompanied child migrants meant that the state had to offer some kind of policy response both in order to protect child migrants at risk and to defend against the risk of child migrants seen as threatening outsiders - as, for instance, suspected gang members. A second key factor was the developing international consensus on children's rights and the UNCRC, which in fact provided that ratifying states must take children and their rights into account in policy and legislation, including in the areas of migration and asylum. During this time, there was also more attention being given to refugee children in public debate and in research. ${ }^{144}$ Bhabha notes how the trend towards developing more effective

\footnotetext{
${ }^{142}$ Bhaba, Child Migration and Human Rights, 3. Among the first policy documents, according Bhabha, was the UNHCR Guidelines on Policies and Procedures in Dealing with Uaccompanied Children Seeking Asylum [1990s with the UNHCR]

${ }^{143}$ Bhabha, Child Migration and Human Rights, 3.

144 Ibid.
} 
implementation strategies; the mainstreaming of children's rights; the increased political attention paid to migrating children; the search for new legal tools and procedures, concepts and policies; and the growth of institutions specifically targeting asylum-seeking children all made the child more visible. ${ }^{145}$

The academic interest in children and migration has increased significantly over the last decade. ${ }^{146}$ In their introduction to a special issue of the Journal of Ethnic and Migration Studies devoted to 'Transnational migration and the study of children', the editors state, much in the same way as Bhabha, that '[c]hildren are not simply a neglected empirical group, whose perspectives are rarely considered; children can also provide researchers with important insights concerning the nature of transnationalism if the phenomenon is considered through their eyes'. ${ }^{147}$ The increased interest in children and migration can be seen as a reaction against a general dearth of knowledge about migrating children. Data about children was scanty and generally focused on special vulnerable groups in which the child was regarded as the adults' 'luggage' or as otherwise embedded in or subordinated to the family. ${ }^{148}$ As a consequence, the child was represented as 'passive, needy and different', and during the migration process the perspectives of children were overshadowed by those of adults and by their decision making and experiences. ${ }^{149}$

Interest in children's roles, experiences and perspectives with respect to transnational migration has gained ground within migration research and in childhood studies, in part due to this lack of data and the dominance of traditional assumptions about children, childhood and family. ${ }^{150}$ We can here speak of a childhood turn in which particular interest is paid to the perspec-

\footnotetext{
145 Ibid., 6.

146 See e.g. Madeleine E. Dobson, 'Unpacking children in migration research', Children's Geographies 7, No. 3 (2009): 355-60; Charles Watters, Refugee children: Towards the next horizon (Abingdon: Routledge, 2008); Marisa O. Ensor and Elð̈ieta M. Goździak (eds.), Children and Migration: At the Crossroads of Resiliency and Vulnerability (Basingstoke: Palgrave Macmillan, 2010); Caitríona Ní Laoire et al. (eds.), 'Special issue: Childhood and migration: mobilities, homes and belongings', Childhood 17, No. 2 (2010): 155-287; Caitríona Ní Laoire et al. (eds.), 'Special issue: Transnational Migration and Childhood', Journal of Ethnic and Migration studies 37, No. 8 (2011): 1159-293; Katy Gardner, 'Transnational Migration and the Study of Children: An Introduction', Journal of Ethnic and Migration Studies 38, No. 6 (2012): 889-912.

${ }^{147}$ Gardner, 'Transnational Migration'.

${ }^{148}$ Marjorie Faulstich Orellana et al., 'Transnational childhoods: The participation of children in processes of family migration', Social Problems 48, No. 4 (2001): 572-91; Dobson, 'Unpacking children'; Laoire et al., 'Special issue: Childhood and migration' and 'Special issue: Transnational Migration'.

${ }^{149}$ See e.g. Laoire et al. 'Special issue: Childhood and migration' and 'Special issue: Transnational Migration', 1159 ff.; Dobson, 'Unpacking children'.

${ }^{150}$ See e.g. Laoire et al. 'Special issue: Childhood and migration' and 'Special issue: Transnational Migration', 1159 ff.; Dobson, 'Unpacking children'.
} 
tives, roles and experiences of children as active participants and rights bearers in the migration process. Maren Bak contextualises this turn both historically and scientifically as developing alongside the sub-discipline of the sociology of childhood and in the wake of the UNCRC. ${ }^{151}$ A feature of this childhood turn is that it focuses on children as subjects in their own right and on how the lives of children and the conceptions of childhood change with different social and historical contexts. ${ }^{152}$ In this line empirical studies have been carried on, based on interviews and participant observations, of children's experiences and the ways in which they actively construct their own social lives; but there has also been studies focused on policy analysis at the macro level. ${ }^{153}$

\section{Asylum-seeking children between universal rights and immigra- tion control}

One particular area of research about child migration has concerned itself with the rights of children in the asylum process. In the same way as the UNCRC has been influential in addressing children's rights in a wide range of other fields, such as education, poverty, social services, child labour, political participation, etc. (as described in chapters two and three), a similar pattern shows up in research about children's experiences of the asylum process. In Bhabha's analysis, which draws on data from a variety of countries around the world, she states that despite a growing recognition of children's fundamental rights to protection, family life, education, health care, participation, etc., these rights are in many cases not enforceable in practice for asylum-seeking children. ${ }^{154}$ She explains that the gap between theory and practice arises because of the fact that a large group of migrant children are de facto or functionally stateless. The solution, she suggests, must be a 'bottom-up' approach in which 'naming, shaming and aggressive mobilization of advocacy strategies' are essential to secure the fundamental rights of this group'. ${ }^{155}$

Bhabha's claim about the gap between theory and practice in the case of asylum-seeking children follows what in chapter two was described as the

\footnotetext{
${ }^{151}$ Maren Bak and Kerstin Von Brömssen (eds.), Barndom och Migration (Umeå: Borea, 2013). Children and childhood have over last thirty years been researched within the field of childhood studies from various disciplinary perspectives such as sociology, history, psychology, anthropology. See e.g. James, Jenks and Prout, Theorizing childhood; Mary Jane Kehily (ed.), An Introduction to Childhood Studies, 2nd ed. (Maidenhead: McGraw Hill, 2008); Michael Wyness, Childhood and Society, 2nd ed. (Basingstoke: Palgrave, 2012).

${ }^{152}$ James, Jenks and Prout, Theorizing Childhood; Kehily, An Introduction; Wyness, Childhood.

153 Watters, Refugee children.

${ }^{154}$ Bhabha, 'Arendt's Children'; see also Gregor Noll, 'Why Human Rights Fail to Protect Undocumented Migrants', European Journal of Migration and Law 12 (2010): 241-72.

155 Bhabha, 'Arendt's Children', 451.
} 
top-down approach: it calls for better implementation of the rights set out in the UNCRC or the ECHR. Just as this strand of research has come to dominate scholarship on children's rights in areas such as education, social work, health, etc., it has also become prevalent in the field of migration. In this area of research, from the fact that asylum-seeking children's rights are unenforceable in practice the conclusion is drawn that more universal children's rights and a better implementation of international law are what is needed. It is at this point, however, that I think childhood scholars with a strong focus on the UNCRC and the protection of the universal rights of children tend to overlook some of the fundamental dilemmas and theoretical difficulties intrinsic to the idea and practice of human rights in the context of migration and immigration control. The difficulty in enforcing human rights for migrants is not unique to children, and by relating the rights of asylum-seeking children to the wider political-theoretical debate in this area I which to enrich the analysis.

As Arendt notes, the paradox of the contemporary idea of human rights is that while human rights belong to us in virtue of our humanity, the realisation of them is intimately bound up with our membership of political communities. And if such community is lost, which is the case for large groups of displaced people today, human rights become unenforceable in practice. ${ }^{156}$ Benhabib points out in a similar vein: 'From a philosophical point of view, transnational migrations bring to the fore the constitutive dilemma at the heart of liberal democracies: between sovereign self-determination claims on the one hand and adherence to universal human rights principles on the other'. ${ }^{157}$ The right of sovereign states to control immigration is, both from a historical and from a philosophical point of view, rather well established and uncontroversial. ${ }^{158}$ This conventional assumption has, however, been challenged e.g. by liberals over the last years. ${ }^{159}$ Some have argued that a restric-

\footnotetext{
${ }^{156}$ Hannah Arendt, The Origins of Totalitarianism (Mariner Books, 1973), $291 \mathrm{ff}$.

${ }^{157}$ Benhabib, The Rights of Others, 2.

${ }^{158}$ The sovereignty of the state and the right to self-determination were at the heart of the development of the modern state order after the Westphalian peace and have been prominent concepts in political thought from the sixteenth century until today - e.g. in the classical writings of Machiavelli, Bodin and Hobbes (Benhabib, The Rights of Others; Wilcox, 'The Open Borders Debate'; Wellman and Cole, Debating the Ethics of Immigration). One of the most famous contemporary defenders of a traditional position on the right to self-determination is Michael Walzer. In his Spheres of Justice, he argues that people are members of groups that constitute political communities (not necessarily states). As members of a political community, people need to be able to make decisions about who is to become a member and who is not in accordance with their understanding of the 'nature of the political community' (Spheres of Justice, 32). David Miller is another recent proponent of the right of nations to control their borders and restrict immigration. He emphasises nationality and claims that individuals have a basic right to control their culture and to form it in accordance with their own wishes. (Miller e.g. 'In Defense of Nationality', 'On Nationality and Global Equality' and 'Nationality: Some Replies', Journal of Applied Philosophy 14, No. 1 (1997): 69-82).

${ }^{159}$ Wilcox 'The Open Borders Debate'.
} 
tive approach to the movement across borders is inconsistent with basic liberal egalitarian ideals of freedom, equal opportunity and moral equality. ${ }^{160}$ Others have criticised restrictions on migration from a global justice perspective and have argued that liberal democratic states have a moral obligation to admit immigrants as a response to global injustices. ${ }^{161}$ In these debates there is, however, a striking absence of discussion of migrant children as a distinct category. ${ }^{162}$ When they are mentioned, they are portrayed as vulnerable, in need of special protection or as citizens in the making whose interests are subordinated to those of their parents. There is a lack of systematic enquiry into childhood specifically. In a similar way, child migrant scholars have only engaged with the more general political-theoretical questions at stake in their enquiries into the rights of asylum-seeking children to a very limited extent. One important contribution of this thesis is therefore that it facilitates a mutual communication between these two fields of research.

\section{International studies of the rights of asylum-seeking children}

One common observation made by child migrant scholars is that asylumseeking children straddle two normative orders. They are either positioned as 'asylum seekers', with the associated discourse of inclusion in or exclusion from the nation state, or they are positioned as 'children', with the associated discourse of care, welfare protection and universal rights. ${ }^{163}$ Watters argues that states' responses to refugee children typically follow one of two trajectories: the first is concerned with the welfare of the child and is underpinned by various national and international instruments and the second is concerned with the security of the territory. ${ }^{164}$ Similarly, Bhabha discusses how inconsistences in state policy concerning unaccompanied minors should be

${ }^{160}$ Carens 'Aliens and citizens'; Joseph Carens, 'A Contextual Approach to Political Theory', Ethical Theory and Moral Practice 7 (2004): 117-32.

${ }^{161}$ E.g. Carens, 'Aliens and citizens'; Risse, 'Immigration'.

${ }^{162}$ In the analysis in Josefsson, 'Children as Moral Subjects', I take as my starting point the reviews of Bader ('The Ethics of Immigration'), Seglow ('The Ethics of Immigration'), Wilcox ('The Open Borders Debate') and the works of Joseph Carens and David Miller in order to shed light on children as subjects in the open/closed borders debate. Carens and Miller are two important and active contributors to the debate and represent two opposing approaches to immigration, arguing for more open borders and for more restricted borders, respectively. [Their contributions have been identified in some distinguished international scientific journals of politics, ethics, and philosophy that also include other contributions associated with the debate between them. The Journals used in the study: Ethics, The Review of Politics, Ethical theory and Moral practice, Ethics and international Affairs, Ethics and Global Politics, Journal of Applied Philosophy]

${ }^{163}$ Jaqueline Bhabha, 'Minors or Aliens? Inconsistent State Intervention and Separated Child Asylum-Seekers'. European Journal of Migration and Law 3, Nos. 3-4 (2001): 283-314 and her 'Arendt's Children'; Giner, 'The Politics of Childhood'; Sandberg, 'The Role of National Courts'; Vitus and Lidén, 'The Status of the Asylum-seeking Child'; Watters, Refugee children; Liv Stretmo, 'Governing the unaccompanied child: Media, policy and practice', PhD Thesis, Gothenburg University, 2014; Ascher and Eastmond, 'In the Best Interest of the Child?'

164 Watters, Refugee children. 
seen in the light of a clash between two opposing normative frameworks immigration enforcement and welfare protection. ${ }^{165}$ Lidén and Vitus have conducted a comparative study of discourse, policy and practice in Denmark and Norway using materials from schooling, asylum hearings and analysis of the grounds cited in cases in which asylum is granted. ${ }^{166}$ They find that while in Norway the discourse of national border control competes equally with that of the protection of the child, in Denmark the discourse of national border control has gained hegemony. They demonstrate that in Norway the positioning of the child as both asylum seeker and child makes possible the child's right to normal schooling and to being heard in the asylum process, and it makes it more likely that the child will be granted residence permits based on his or her attachment to Norway. By contrast, in the Danish context, the positioning of children primarily as asylum seekers is associated with a right to residence permits only in cases of parental illness, with no separate hearings and a limited access to schooling. ${ }^{167}$

In a case study of UK policy and public discourse, Andersson argues that the government's arguments for the protection of asylum-seeking children and the avoidance of 'harm' to children at risk of, for example, trafficking, have become central to immigration enforcement. ${ }^{168}$ The language of protection and harm has made it possible to recast immigration enforcement as a protection of children's rights, and it has cast the state in the role of the protector of children whilst hindering children's ability to define their own interests and to speak for themselves about what is best for them. The strategy has been a way to reconcile the fundamental liberal dilemma between the promotion of human rights, on one hand, and the rights of citizens, on the other. This is deeply problematic, she states, since the 'prevention of harm to migrants is a poor basis on which to try to develop "ethically comfortable" enforcement mechanisms'. It relies on an idea of harm that is so vague that it equates compulsion for the good of others with compulsion for your own good, and it makes invisible the role of the state in controlling immigration and reinforces the dependencies and vulnerabilities of migrant children. ${ }^{169}$ In a similar vein, Giner argues that UK government rhetoric seems to indicate an awareness on the part of the government of the risk it runs of being seen as disregarding children's rights, and it therefore systematically avoids presenting asylum-seeking children as undeserving or as a threat to society. ${ }^{170}$ Instead, the best interests of the child have to be adjusted to 'fit

\footnotetext{
165 Bhabha, 'Minors or Aliens?', 293 ff.

${ }^{166}$ Vitus and Lidén, 'The Status of the Asylum-seeking Child', 62.

167 Ibid.

${ }^{168}$ Andersson, 'Where's the harm in that?'

169 Ibid., 1255.

${ }^{170}$ Giner 'The Politics of Childhood', 257
} 
within the context of effective immigration control', rather than the other way around.

A more comprehensive study of the rights of asylum-seeking children has been conducted by Ciara Mary Smyth. In the study, she addresses the question of whether the Common European Asylum System (CEAS) complies with the rights of the child by contrasting the normative standards of international child rights law with the standards of treatment of child asylum seekers and refugees in the CEAS. Through a rigorous legal analysis, she elucidates the meaning of the relevant rights of the child with the aim of assessing whether the CEAS instruments comply with those rights. She finds that the CEAS does not, in general, comply with the rights of the child in international law: some rights are recognised while others are not. In one sense, Smyth seeks, just as does this thesis, to understand the meanings given to children's rights in the context of asylum. But Smyth's study differs from this one in that it is primarily concerned with the meanings as formulated in positive law and with the issue of how to make policy comply with these meanings according to a top-down approach. To study the meanings and uses of children's rights in the context of asylum and migration policy requires a detailed and thorough understanding of the contexts and the practices in which they are operative, as Bhabha, Lidén and Vitus, and Smyth have shown. To this end, this thesis examines one such context - namely, Sweden. This will be the concern of the next chapter.

\section{Studies of the rights of asylum-seeking children in the Swedish context}

One avenue of research into the issue of asylum-seeking children in the Swedish context has been concerned with Swedish public and policy discourses about child migrants over the last few decades. Marita Eastmond has shown that the public debate about asylum-seeking children goes back at least to the early 1990s, when Sweden admitted nearly 50,000 refugees from BosniaHerzegovina in the wake of the ongoing war in the former Yugoslavia. ${ }^{171}$ An intense public debate took place which polarised opinion between an exclusionary stance of restricting immigration and a more inclusive humanitarian position, much as the international studies of Bahbha, Watters, and Lidén and Vitus demonstrate. ${ }^{172}$ Eastmond describes how the asylum-seeking child was positioned between two countervailing discourses at this time: firstly, a discourse of 'fear and mistrust built upon the notion of a refugees as the "unwanted other"' and, secondly, a discourse that cast refugees as the 'traumatized victims of war'. ${ }^{173}$ The asylum-seeking child has thus been seen, on

\footnotetext{
${ }^{171}$ Marita Eastmond, 'Egalitarian Ambitions, Constructions of Difference: The Paradoxes of Refugee Integration in Sweden', Journal of Ethnic and Migration Studies 37 (2011): 277-95.

172 Ibid.

${ }^{173}$ Ibid. 278.
} 
the one hand, as in need of urgent care and, on the other, in relation to a public need for control. ${ }^{174}$

In her dissertation, Liv Stretmo examines how Swedish and Norwegian newspapers and public officials from 2000 to 2010 have positioned 'missing' unaccompanied minors within a more general discourse of irregular migration. ${ }^{175}$ The protection discourse in this context bears some similarities to the UK context as described by Andersson and Giner. Stretmo shows how public narratives about missing and unaccompanied children tend to view these children as engaging in strategic asylum behaviour, as 'voluntary absconders' in need of care from social services, schools and migration authorities. The missing, unaccompanied child becomes a problematic figure, a potential danger to the asylum system. This implies a demand for official action, surveillance and monitoring, given the potential security risks that these children seem to constitute. ${ }^{176}$ I share Eastmond's and Stretmo's interest in public discourses about migrant children and children's rights, but my research interest is more specifically focused on the rights of asylum-seeking children, both in terms of claims made in the media (article two) and the theoretical underpinnings of such rights (article four).

Another avenue of research has focused on the rights of asylum-seeking children through policy analysis and interviews with legislators. Andersson demonstrates, for example, that beginning in the 1990s, children's rights entered into and influenced Swedish asylum policy and legislation in different phases of the asylum process but that they did not in any significant way limit the ability of the state to control immigration. ${ }^{177}$ For the purposes of this thesis, Daniel Hedlund's recent dissertation is particularly relevant: it studies how unaccompanied asylum-seeking minors and their needs and interests are perceived both by legislators who play key roles in policy making and by the Swedish migration board at the time that policy is put into practice. ${ }^{178}$ In this way, he addresses some key issues and challenges regarding the rights of unaccompanied minors and highlights the mutual relationship between politics and law. At the level of the legislators, he finds that they perceive the rights, needs and best interests of unaccompanied asylum-seeking minors primarily in relation to age. His findings demonstrate, further, that legislators largely see the duties and responsibilities for protecting the rights

\footnotetext{
${ }^{174}$ Mehek Muftee, “"That will be your home”: Resettlement preparations for children and youth from the Horn of Africa', PhD Thesis, Linköping University, 2014, 22; Eastmond, 'Egalitarian Ambitions'.

${ }^{175}$ Stretmo, 'Governing the unaccompanied child'.

${ }^{176}$ Ibid., 256.

177 Andersson, 'Where's the harm in that?'

${ }^{178}$ Daniel Hedlund, 'Drawing the limits: Unaccompanied minors in Swedish asylum policy and procedure', PhD Thesis, Stockholm University, 2016.
} 
of unaccompanied minors as only binding actors somewhere else - for instance, in their home country through family reunification. ${ }^{179}$ Hedlund thus suggests that unaccompanied minors are, in this way, not considered to be genuine rights bearers but rather are seen as subjects whose welfare is to be protected. At the level of the migration agency, Hedlund's investigation of over 900 decisions shows that the credibility of the child becomes crucial evidence in the outcome of decisions. ${ }^{180}$ The decision makers, Hedlund remarks, seem to assume that unaccompanied minors have the capacity to tell a consistent and detailed story about their grounds for asylum, and if they do not meet these requirements, they are viewed with a mistrust indicative of the culture of suspicion at the agency.

Several other studies have like Hedlund payed attention to what role children's rights have played in decision making about residence permits in the asylum process. ${ }^{181}$ Primarily, the material for these studies has been selected from the level of the migration agency and the migration courts. These studies have for the most part focused on the best interest of the child (and the right to be heard) and demonstrated how the principle has a much more prominent position in legislation than it has in the practice of decision making. There has, however, been no comprehensive study that takes a particular interest in children's rights or in the highest instance in the asylum process, the Swedish Migration Court of Appeal. Since the MCA is the legal instance that provides the lower instances with precedents and, in virtue of being the final instance contains some of Sweden's top legal experts, its decisions represent, in this sense, the ultimate acts of the Swedish state. For this reason, I focus on the decision making of the MCA in article one.

In article one of this thesis, I examine the concept of the best interest of the child and how it is given meaning and is used in the arguments of the court. Almost two decades ago, Schiratzki conducted an extensive investigation of Swedish case law relating to children and residence permits at the Swedish Aliens Appeal Board from 1997 to 1998 (at that time, the Swedish Aliens Appeal Board was the final instance of the asylum process). She found

\footnotetext{
${ }^{179}$ Daniel Hedlund, “Beard boys”: Standing in the way of a transformation of the self', in Invisible boy: The making of contemporary masculinities, eds. C. Hällgren, E. Dunkels and G-M. Frånberg (Umeå: Umeå universitet, 2015), 90; Hedlund, 'Drawing the limits', 248.

${ }^{180}$ Hedlund, 'Drawing the limits', 92.

${ }^{181}$ Anna Lundberg, 'The Best Interests of the Child Principle'; Anna Lundberg, 2009, 'Barns rätt att komma till tals i asylprocessen - om likheter och diskrepanser mellan policy och praktikin current themes', in Asylum Seekers in Sweden - A Just and Dignified Reception for Children and Adults?, ed. Björn Fryklund and Anna Lundberg (Malmö: Malmö Institute for Studies of Migration, Diversity and Welfare (MIM) and Department of International Migration and Ethnic Relations (IMER) Malmö University, 2009); Lisa Ottosson and Anna Lundberg, “People Out of Place"? Advocates' Negotiations on Children's Participation in the Asylum Application Process in Sweden', International Journal of Law, Policy and the Family 27, No. 2 (2013): 266-87; Johanna Schiratzki, 'The Best Interests of the Child in the Swedish Aliens Act', International Journal of Law, Policy and the Family 14, No. 3 (2000): 206-25.
} 
that the BIP was not applied in an open way, allowing for the facts of individual cases to be taken into consideration, as was initially the intention behind the principle, but that it was used essentially as a traditional legal rule, such that the judgments conformed strictly with the guidelines from the travaux préparatoires. ${ }^{182}$ The BIP was mainly used in assessments of cases concerning family reunification and in decisions about the granting of residence permits on humanitarian grounds. Even though some years have passed since Shiratzki's investigation was conducted, it is relevant because it can be valuable to compare the ways in which the BIP was interpreted in the previous Swedish asylum system with the ways in which it has been interpreted after the legislative change in 2005-2006. Further, it constitutes one of the more comprehensive studies that has been conducted about children's rights and the best interests of the child.

In their studies of the Swedish asylum process, both Nilsson and Lundberg discern a discrepancy between the intention of national and international legislation about children's rights and the exercise of authority at the level of the migration board and the Aliens Appeals Board. ${ }^{183}$ Nilsson arrives at a similar conclusion as Schiratski in that the best interest of the child is primarily taken into consideration in relation to humanitarian concerns. Moreover, she shows how particular considerations relating to the children themselves are rarely taken into account and that, instead, general considerations about the situation in the home countries are given weight and provide the basis for decisions. ${ }^{184}$ According to Lundberg, considerations of the best interest of the child were taken into account mainly in applications that were rejected, and she concludes that children's rights are treated as less important than the national interest in keeping immigration numbers down. ${ }^{185}$ The studies of Hedlund, Schiratzki, Nilsson and Lundberg all provide an important backdrop to the analysis and results of article one in this thesis. And, as that article will demonstrate, some of their observations about

\footnotetext{
182 Schiratzki, 'The Best Interests of the Child'. According to Schiratzki, it has been claimed that the BIP "is to be characterized as an "open concept" with no definite content, thus enabling the agent implementing the law to make a free, discretionary assessment considering all of the issues relating to the individual child' ('The Best Interests of the Child', 207). Ref Gov Bill Prop 1997/98:7. Schiratzki's investigation was conducted under the former asylum system in which decisions from the Migration Board could be appealed to the Aliens Appeals Board. In the article, I use the term travaux préparatoires to refer to the government bills (Sv. Transl. "Proposition") preceding the Aliens Act that are repeatedly referred to by the court to determine the intention of the legislators.

${ }^{183}$ Lundberg, 'Barns rätt att komma till tals i asylprocessen' and 'The Best Interests of the Child Principle'; Nilsson, Barn i Rättens Gränsland.

${ }^{184}$ Nilsson, Barn i Rättens Gränsland, $241 \mathrm{ff.}$

185 Some of the other findings were: children were not heard to the extent expected in light of Swedish legislation, children's individual grounds for asylum were seldom addressed in interviews with them, children's responses were not taken seriously in the assessment of asylum claims and the best interest of the child was mainly used to legitimate rejected asylum applications.
} 
the ways in which children's rights come into play in the asylum process bear similarities with the observations made in this thesis (although others do not).

Thus far, I have introduced the background to and aims of this thesis (chapter one). In chapters two and three, I presented a conceptual and theoretical framework for the thesis. In this chapter, the focus has been on previous research concerning migration and the rights of asylum-seeking children. In the next chapter, I present the material and methodological considerations underlying the articles before turning the attention to the summaries of the articles and the discussion. 


\section{MATERIAL AND METHOD}

In this chapter, I outline and discuss the material and method of the thesis. I begin with a general introduction before presenting the material and methodological considerations for each study. The discussions of articles one and two have their own headings, and articles three and four are presented under the same heading.

The general methodological approach of the thesis is to combine empirical and qualitative research with theoretical and conceptual analysis. The empirical investigations, presented in articles one and two, focus on the rights of asylum-seeking children as they are expressed in two different settings in Swedish society: in the decision making of the Swedish Migration Court of Appeal (MCA) and in the reporting of the daily newspaper Dagens Nyheter (DN). Through textual analysis, I focus on how arguments and claims about children's rights and immigration control are constructed in these different contexts. In the theoretical investigations, presented in articles three and four, the rights of asylum-seeking children are analysed in dialogue with contemporary political-philosophical literature about membership, rights and borders. More specifically, I relate the issue of the rights of asylum-seeking children to Martha Nussbaum's capability approach and Seyla Benhabib's discourse ethics.

My study draws on childhood studies, an interdisciplinary field of research. The implications of social and political phenomena like the controversies over the rights of asylum-seeking children are seldom restricted only to a single discipline. It is thus crucial to draw on different disciplines and fields in order to achieve the aim of this thesis. In particular, I have sought to bring political philosophy into the field of childhood studies and vice versa. Over the last thirty years, anthropology, sociology, history and psychology have dominated childhood studies. ${ }^{186}$ This has affected the ways in which children's rights and migration issues, for instance, have been analysed. However, a study of the nature, function and normative foundations of children's rights in the context of migration can benefit from more dialogue with contemporary theoretical research about international law, human rights, asylum, migration and borders in legal and political theory.

\footnotetext{
${ }^{186}$ James, Jenks and Prout, Theorizing childhood; Kehily, An Introduction; Nick Lee, Childhood and society: Growing up in an age of uncertainty (Buckingham: Open University Press, 2001); Carmel Smith and Sheila Greene, Key Thinkers in Childhood Studies: Reflections on the Making of a Field (Bristol: Policy Press, 2014); Wyness, Childhood.
} 
Moreover, my study draws on political philosophy. Mainstream legal and political theory has for many years marginalised and neglected the political subjectivity of children and children as a category. ${ }^{187}$ Although some discussions of children and their rights have taken place in political philosophy in the last few decades, considerations relating to childhood have thus far not influenced philosophers in the same way as have, for example, considerations relating to gender, class and ethnicity. This is despite the fact that children constitute about one-third of the world's population. Moreover, it appears as though the broad empirical knowledge base about children and childhood that has grown out of the expanding field of childhood studies over the last decades can provide essential input into the formulation and framing of the political-theoretical debate about children. ${ }^{188}$

When conducting research in the social sciences and humanities, one must take heed of various ethical considerations: individuals involved in the research must be protected, and laws and ethical guidelines from the international and national research community must be followed. ${ }^{189}$ The documents from the MCA and Dagens Nyheter used in the thesis concern individuals and they contain information of sensitive character. They were publically available before the research project started but despite the public character of the material a number of measures had been taken in order to protect the individuals involved. The MCA-documents were anonymized by the Swedish National Courts Administration even though the original decisions from the MCA are available at the Court administration with names in their virtue of being public documents. ${ }^{190}$ In the case of the Dagens $\mathrm{Ny}-$ heter-material, in most articles the newspaper had taken measures to ensure that information of a confidential nature has been anonymised in order to avoid the possibility of the identification of individuals involved. In other

\footnotetext{
${ }^{187}$ In chapter three, I described some lines of research into children and rights in political philosophy, but these are exceptions to the rule. See e.g. Archard, Children; Archard and Macleod, The Moral and Political Status of Children; Josefsson, 'Children as Moral Subjects'; Wall, 'Can democracy represent children?'; Schrag, 'The Child's Status'; Matthews and Turner, The Philosopher's Child.

${ }^{188}$ I do not suggest that empirical knowledge about a particular situation has a direct link to normative and philosophical arguments. But in order to address questions of social justice or rights claims as they are found in contemporary society constructively, arguments must be empirically informed as well as normatively oriented and theoretically driven. for further discussion about such an approach, see e.g. Nancy Fraser and Axel Honneth, Redistribution or Recognition? a political-philosophical exchange, trans. Joel Golb, James Ingram and Christiane Wilke (London: Verso books, 2003); Carens, 'a contextual approach'.

${ }^{189}$ SFS 2003:460.

${ }^{190}$ The decisions from the MCA are available at the official database of the Swedish National Courts Administration; personal information has been redacted in the documents to maintain confidentiality (http://www.rattsinfosok.dom.se/lagrummet/).
} 
cases, when the articles contain personal information, I assume it has been approved by the person in question. ${ }^{191}$

\section{Article one: the Swedish Migration Court of Appeal}

In 2006, a new Aliens Act and asylum process was adopted in Sweden. According to this Act, the MCA is the final instance for appeal. As a consequence, this court sets the standards regarding legal reasoning and normativity in citizenship and asylum cases. ${ }^{192}$ The intention of the legislation was to improve the 'rule of law, consistency and predictability' in the asylum process by moving the legal assessment of residence permits from the former system, involving an Aliens Board and administered by the government, to the administrative courts, which are formally independent of the government. ${ }^{193}$ The relatively new system and the limited research into precedents set by the MCA, especially in relation to children, suggests the need for closer empirical and theoretical analysis of children's rights in this institution. ${ }^{194}$

The court normally consists of three judges and one reporting clerk and is situated at the Swedish Administrative Court of Appeal in Stockholm. Asylum cases are only one sort of case out of many that come before the judges; they also deal with, for instance, tax cases, social security cases, social service cases, public procurement cases, etc. As the final instance in the Swedish asylum process, the court's decisions serve as precedents for the lower instances. In this respect, the judges play a critical role as interpreters of children's rights and in determining how the universal rights of children are to be taken account of in the domestic practice of immigration control. ${ }^{195} \mathrm{~A}$ study of the

${ }^{191}$ The decisions of the MCA are available at the official database of the Swedish National Courts Ad-ministration; personal information has been redacted in the documents to maintain confidentiality (http://www.rattsinfosok.dom.se/lagrummet/). The articles from Dagens Nybeter are publically available at their homepage and personal information was largely made confidential at the time of reporting - by, for instance, replacing names and omitting specific geographical information.

192 SFS 2005:716

${ }^{193}$ Governmental Bill, SOU 2004/05:170, 105. In contrast to the former system under the Aliens Board, the administrative courts are formally more independent of the government with respect to decisions of particular national interest. Under the old system, the government could control the implementation of the law to a greater extent by partly promulgating ordinances on the interpretation of the Aliens Act, and also through its ability to rule on individual cases of particular importance because of concerns of national security, public safety or relating to Sweden's relations with another power or international organisation. This possibility does not exist in the present process. Schiratzki, 'The Best Interests of the Child', 208; Aliens Act 2005:716; Aliens Act 1989 7:11, section 2; Gov. Committee Dir. 2007:119, 3.

${ }^{194}$ Some legal analysis of MCA cases has been conducted by e.g. Rebecca Stern, Ny utlänningslag under lupp (Stockholm: Röda Korset, 2008); Anna Lundberg, 'Barn i den svenska asylprocessen', in Bak and Brömssen, Barndom, 47-78; Rebecca Thorburn Stern and Hanna Wikström, Migrationsrätt: skyddsbehov och trovärdighet - bedömning $i$ asylärenden (Stockholm: Liber, 2016).

${ }^{195}$ Sandberg, 'The Role of National Courts'. 
rights of asylum-seeking children in the court is ultimately also a way of studying the actions of the Swedish state in this matter.

The material used in this study consists of 39 court decisions of the MCA from 2006 to 2013, which all make reference to the best interests of the child. ${ }^{196}$ I decided at an early stage in the investigation to focus on the principle of the best interests of the child since this is the most commonly referenced principle that provides children with a special status in this context. ${ }^{197}$ The decisions were selected from the official database of the Swedish $\mathrm{Na}$ tional Courts Administration. ${ }^{198}$ During this period, a total of 254 decisions were published by the MCA, of which 71 involved children ${ }^{199}$ and 39 included the key words 'best interests of the child'. ${ }^{200}$ The court decisions are between 4 and 18 pages long and contain reports of the decisions of the MCA and summaries of the decisions of previous instances (the Swedish Migration Agency and the Swedish Migration Court).

The analysis was conducted in three main stages. First, all 39 cases were categorised. One category is family situation. In six of the cases the children were unaccompanied, in eight cases the children were accompanied by two parents, in eleven cases the children were accompanied by a mother, in seven cases fathers were applying for reunification with children in Sweden, in three cases mothers were applying for reunification with children in Sweden and in four cases the family situation was 'other'. ${ }^{201}$ Another category concerns whether residence permits were granted or rejected. Of the 39 decisions, 28 cases were rejected or passed back to previous instances and 11 were granted residence permits. I found no particular correlation between family situation and whether a residence permit was granted or not.

\footnotetext{
${ }^{196}$ The analysed material is comprised of summaries of the formal decisions chosen by the court as important precedents of public interest. Every year, the court rules on approximately ten thousand decisions, and from these they choose to publish those they deem to be of special interest as precedents.

${ }^{197}$ Aliens Act 2005:716, Ch. 1 \$10; UNCRC, Article 3.

${ }^{198}$ The official Swedish database that presents Swedish Jurisprudence is provided by the Swedish National Courts Administration. For more information, see: http://www.rattsinfosok.dom.se/lagrummet/

${ }^{199}$ To arrive at this figure, the selection was made in different steps. First, of the 254 decisions published in the database during this period, 124 were selected using the key word 'child' (Swe. barn). Of these 124 decisions, 71 were identified as involving a child as an applicant or a family member who was affected by the decision; 31 did not involve a child but referred to the word 'child' in a general sense, e.g. as part of a reference to a legal provision; 23 were classified as 'other', referring to children in indirect ways, such as when a child as a family member is situated in another country but is not the plaintiff or when the applicant is pregnant and the child has not yet been born.

${ }^{200}$ The key words used in Swedish were 'barnets bästa' ( 36 decisions) and 'barnens bästa' ( 3 decisions).

${ }^{201}$ For example, an adult without children, a couple in which one of the parties was underage or in which a child arrived with a mother who later left the country.
} 
In a second stage, key passages were identified in which the interests of children were explicitly discussed. The cases were categorised with regard to the extent of the court's reference to the best interests of the child. In 10 of the decisions, one finds hardly no reasoning about BIP at all, in 12 there is some limited reasoning and in 13 the reasoning is more extensive. Four of the cases were irrelevant for my analysis. This categorisation was followed by a closer analysis of what meanings and substantial content were given to the best interests of the child and what role this principle played in the argument of the court. The excerpts were categorised into themes that represent salient patterns in how the court reasoned about children's interests.

Two questions guided my analysis of the arguments of the court: what is given weight, and what weight is given, to the best interests of the child? The questions are inspired by David Archard's analytical work on the best interests of the child. ${ }^{202}$ These questions cannot be fully separated in theory or practice but are used as tools to structure the analysis. The first question - what is given weight - refers to the meaning and the substantial content given to the concept of the best interests of the child in the argument of the court. For example, which norms, facts and claims are relevant in the argument for the best interests of the child? By meaning, I mean to refer to the expression of the BIP as it takes on an explicit form in the argument of the court and the way it is given meaning when it is placed in relation to surrounding expressions. ${ }^{203}$ The second question - what weight is given - refers to how the interests of the child are used and given weight in relation to other principles, rules and interests. Here, a particular focus is on children's interests in relation to the state's interest in controlling immigration.

With regard to the first question, I identified how the best interests of the child were frequently explained in relation to family and home country, bealth, and adaptation to Sweden. These themes and patterns were not the only ones identified, but I found them to be the most salient. The BIP was, for example, also reasoned about both explicitly and implicitly in relation to issues of age and maturity, evidentiary requirements, the responsibility of children for staying illegally in the country and in relation to the criminal acts of parents.

In a third stage of my analysis, I examined the second question, the court's weighing of the best interests of the child, on the one hand, and the state's interests in controlling immigration, on the other. Here, I paid particular attention to the way the best interests of the child were given weight and normative force in the argument of the court.

\footnotetext{
${ }^{202}$ Archard, Children, 60; Archard and Skivenes, 'Balancing a Child's Best Interests'.
}

${ }^{203}$ Koskenniemi, From Apology to Utopia, $6 \mathrm{ff}$. 


\section{Article two: Dagens Nyheter}

In this article, I analyse the public debate about children's claims for asylum. The material consists of articles from the largest Swedish morning newspaper, Dagens Nybeter. This paper is a site in the Swedish public sphere in which the rights of asylum-seeking children have been publically discussed for years. Accordingly, it is a forum that can potentially play a critical role in reviewing state policy and in which public reasoning contests the meanings given to children's rights in legal reasoning. The reason for choosing DN as a primary source for investigating children's claims for asylum is that it is at the centre of national political debate. At the same time, however, DN's ability to channel arguments and narratives from more peripheral and potentially more radical debates - taking place on social media, for instance - is somewhat limited. ${ }^{204}$

The analysis is based on news reports, in-depth feature reporting, opinion pieces, editorials, brief notes, and letters to the editor concerning children at risk of deportation published in DN during the period 2000-2013. My basic methodological claim is that this material can be used in order to analyse the social interaction or the socio-political practice of rights in the public sphere that challenges the official legal view of who and what is to be recognised by law. ${ }^{205}$ The media, in this case $\mathrm{DN}$, thus becomes an arena in which actors in the public sphere deliberate and make claims about asylum-seeking children and their rights. ${ }^{206}$

In a first step in the analysis, a search was conducted in the database 'Mediearkivet' using the key words 'child', 'deport' and 'deportation'. The search returned a total of 723 articles, among which 337 concerned other non-relevant topics, 200 were about the general debate on immigration, 97 were about the general debate on children and immigration and 89 concerned specific cases $(n=49)$ of children at risk of deportation. The 89 articles/49 cases concerning specific children at risk of deportation were selected for closer analysis. The cases were relatively evenly distributed over the years, with an average of three to four cases yearly with some peaks of six to seven cases in 2005, 2009 and 2010. Among the 49 cases, 37 concerned children

\footnotetext{
${ }^{204}$ More radical positions, which Fraser would refer to as counterpublics (Fraser, 'Rethinking the Public Sphere',61), can be found in e.g. web communities and blogs like www.avpixlat.info and www.flashback.org, and http://www.folkkampanjforasylratt.se/blogg/.

${ }^{205}$ Lindahl, Fault Lines of Globalization; Lister, 'Why Citizenship'; Fraser, 'Rethinking the Public Sphere'.

${ }^{206} \mathrm{I}$ refer here to the public sphere in a Habermasian tradition, designating an arena in modern societies in which citizens enact political participation and deliberate about their common affairs. The public sphere is conceptually distinct from, and in principle can be critical of, the state (Fraser, 'Rethinking the Public Sphere', 67. See also Jürgen Habermas, The Structural Transformation of the Public Sphere: An inquiry into a category of Bourgeois Society (Cambridge: Polity Press, 1989)).
} 
in families and 12 concerned unaccompanied children. In the reporting, there were slightly more girls than boys, followed by a group of children referred to only as 'siblings', and thus of unknown gender. The most frequently occurring countries of origin for the children involved in the cases were Afghanistan (five) and Azerbaijan (four), followed by Kosovo (three), Serbia (three) and Turkey/Kurdistan (three). At least 26 cases of the 49 (53 per cent) were granted a residence permit after the reporting and appeal.

This categorisation was followed by an analysis of arguments. All cases were analysed, with special attention paid to the arguments supporting the children's claim to asylum. The following question was posed: what are the reasons supporting the claim that this particular child ought to get a residence permit? My assumption here is that the arguments found in media reporting are historically and contextually embedded. ${ }^{207} \mathrm{My}$ analysis was not conducted in relation to any sophisticated system of ideal types of elements or structures of argumentation found in some traditions of argument analysis. ${ }^{208}$ The focus was instead on analysing the arguments as they appeared in public deliberations in close relation to the context and discourses in which they are expressed, with a stress on the content of the claims and arguments and the premises underpinning them. ${ }^{209}$

In the course of the analysis, three sorts of claim gradually emerged. First, there were many claims about the poor state of the health of asylumseeking children. Second, some claims referred to children in special need of protection from a risky, threatening and uncertain future; these arguments thus emphasised the importance of the child's fundamental well-being or ability to live a decent life. Third, there were claims of community, which referred to the fact that the child had become a member of a community and so ought not to be deported. These three lines of argument are to some extent overlapping and interdependent, but they are also of a distinctive character and are backed by their own reasons. Of the 49 cases, claims about health were identified in 18 cases, claims about well-being in 25 cases and claims about community in 9 cases. In article two, I chose a small number of cases that illustrate and exemplify broader patterns of claim making and contain important characteristics that are representative of the claims found in the other cases, rather than going through each and every case in turn.

\footnotetext{
${ }^{207}$ Fraser 1990, p. 59 ff; Frans H. Van Eemerren \& Peter Houtlosser ed. Argumentation in Practice. (John Benjamins Publishing Company 2005), p. 2.

${ }^{208}$ Fairclough and Fairclough, Political Discourse Analysis; van Eemerren and Houtlosser, Argumentation in Practice. For instance, I do not adopt the technical and normative analysis of Stephan Toulmin, the linguistic speech-act theory of John Austin or the critical discourse analysis of Fairclough.

${ }^{209}$ Fairclough and Fairclough, Political Discourse Analysis.
} 


\section{Articles three and four: Martha Nussbaum's capability approach and Seyla Benhabib's discourse ethics}

Articles one and two are primarily empirically oriented and their aim is to identify how children's claims of asylum are dealt with in the court and in the public debate. In articles three and four, children's asylum claims are approached from a theoretical point of view. Some of the political and ethical questions raised by the two empirical studies are examined using the theoretical frameworks of Martha Nussbaum's capability approach (article three) and Seyla Benhabib's discourse ethics (article four).

The theoretical enquiries of this thesis rests on the assumption that a plausible political or ethical theory needs to be contextually sensitive. I adhere to a kind of 'bottom-up' method or contextual approach to political theory. ${ }^{210}$ This approach is in line with a tradition in the fields of ethics, political philosophy and political theory that over the last few decades has pointed out the ways in which contemporary challenges relating to globalisation, poverty, gender, the environment, discrimination, migration, etc., have highlighted a need for revising and develop traditional political theory. With regard to children, I have already presented, in chapter four, some contemporary approaches that propose to reconsider political philosophy from the perspective of childhood.

In article three, I use Nussbaum's capability approach to analyse some of the normative questions raised by the legal reasoning of the MCA about asylum-seeking children's rights. The main question in this article is whether, and in what way, Nussbaum's capability approach is a fruitful normative framework for understanding some of the key political and ethical aspects of children's rights to asylum. The aim is not only to examine some of the contemporary normative questions related to children's rights to asylum with reference to the capability approach, but also to inquire the prospects and limitations of the approach. As I demonstrate, the capability approach has been influential in a wide range of research fields in recent years, including in the fields of children's rights and childhood studies. However, with only a few exceptions, it has not been brought to bear on the issue of global migration. I ask what this approach might have to offer as a normative framework in relation to the politically urgent question of children's rights to asylum. The article pays particular attention to Nussbaum's ideas of central capabilities as threshold levels, the universal aspirations of her approach and the theory's foundation in the nation state. I outline some of the general societal challenges related to children's rights to asylum and illustrate this by

\footnotetext{
${ }^{210}$ Carens, 'A Contextual Approach'; Fraser and Honneth, Redistribution or recognition?; Veit Bader and Sawitri Saharso, 'Introduction: Contextualized Morality and Ethno-Religious Diversity', Ethical Theory and Moral Practice 7, No. 2, (2004): 107-15.
} 
using two asylum cases from the MCA, which I analyse in terms of the capability approach. This is followed by a discussion of some of the prospects and limitations of her approach with regard to children's rights to asylum.

In article four, Benhabib's discourse ethics theory is used as a theoretical framework for analysing the political controversies around the claims of asylum-seeking children to residence permits. With reference to the principles of reciprocity and democratic iterations, I examine her theory as a way to broaden the theoretical discussion of migration, childhood, and the rights of asylum-seeking children. In the article, I start by outlining some of the pertinent contemporary challenges posed by the rights claims of asylum-seeking children. This is followed by a description of some of the main features of her approach, drawing on her writings on discourse ethics and on migration. I focus in particular on the principle of reciprocity and her concept of democratic iterations. I claim that the rights claims of asylum-seeking children have sparked reciprocal dialogues of justification and suggest that the relationship between asylum-seeking children and the state is best characterised as asymmetrical. Throughout the article, I make use of Benhabib's theory in order to analyse the rights claims of asylum-seeking children, using two cases from the Swedish public debate. I argue that the principle of reciprocity and the concept of democratic iterations can offer a productive normative framework for children's rights in the context of asylum seeking. 


\section{SUMMARY OF ARTICLES}

\section{Article 1: Children's rights to asylum in the Swedish Migration Court of Appeal}

Josefsson, Jonathan. 'Children's Rights to Asylum in the Swedish Migration Court of Appeal'. International Journal of Children's Rights (accepted).

Children's rights to asylum have rendered political controversies in a number of countries in recent years. This article put focus on the translation of nearly universally recognised children's rights principles into a domestic practice of immigration control and explores how legal norms regarding children's rights to asylum have developed in the Swedish Migration Court of Appeal 2006-2013. Court decisions are analysed with focus on the meanings given to the best interests of the child, how this is given weight against state interests of immigration control, and how children's interests are given normative force. It is only in a small minority of cases in which the Best Interests Principle (BIP) in fact does have a decisive normative force in granting residence permits and the meanings and use of children's interests in court argument making evident that the BIP enables both the granting and denial of residence permits. The BIP is doing normative work in double directions.

\section{Article 2: 'We beg you, let them stay!': right claims of asylum- seeking children as a socio-political practice}

Josefsson, Jonathan. “"We beg you, let them stay!": right claims of asylumseeking children as a socio-political practice'. Childhood. Prepublished 7 November 2016, DOI:10.1177/0907568216674785.

Children's rights to asylum have emerged as an urgent political challenge. This article uses a number of cases discussed in Sweden's largest morning paper to analyse claims of asylum-seeking children and how these claims challenge the normative limits of contemporary asylum, concerning what and who ought to be recognized by law. Even though the universality of the child constitutes a running theme, the arguments and the conception of children underpinning the claims are diverse. The article suggests that the claiming of rights as a socio-political practice could be a vital analytical 
approach to studying children's rights and offers a much needed alternative to the dominant mainstreaming paradigm.

\section{Article 3: Children's rights to asylum and the capability ap- proach}

Josefsson, Jonathan. 'Children's Rights to Asylum and the Capability Approach'. Ethical Perspectives 23, No. 1 (2016): 101-30.

The prospect of large populations of children migrating across national borders raises urgent political and ethical questions about children's rights to asylum. In recent years, there has been an increase in scholarly interest in migrating children and children's rights, but this interest has thus far been scant in political theory. The present article uses the Capability Approach to discuss children's rights to asylum and to examine the prospects and limitations of the approach in this context. It underlines that, despite a global consensus on the rights of the child, the political and ethical challenges to children's rights to asylum cannot be reduced to a question of the implementation of universal rights or capabilities of children - a matter of technicalities or mainstreaming of legislation. Instead, the question of children's rights to asylum is a highly political and ethical matter, characterised by ambivalent conceptualisations of children and conflicting interests that continue to pose a considerable challenge to the organisation of the international political and legal system. The Capability pproach has the potential to fill a theoretical gap with regard to children's interests and the setting of threshold levels, although it continues to wrestle with questions of how to confront the asylum-seeking child as a political subject within well-functioning democracies and how to determine a specific list of capabilities and corresponding duties in deliberation between the right to self-determination of nation states and universal entitlements of children.

\section{Article 4: Right claims of asylum-seeking children: a discourse ethical approach}

Josefsson, Jonathan. 'Right claims of asylum-seeking children: a discourse ethical approach' (to be submitted).

In the wake of western state denials of residence permits to asylum-seeking children after longer periods of residency - local communities, anti-deporta- 
tion campaigns and children themselves have rejecting the justifications provided by state authorities and mobilised claims for asylum-seeking children's rights to stay. Thus far, scholars have primarily analysed the normative aspects of the issue along a legalistic or top-down model where children's rights as stated in international law such as the UN Convention on the Rights of the Child have been used as the normative standard upon which the justification and practice of immigration control by western states have been evaluated. Though a legalistic approach can address questions of justification internally to the legal system itself it have difficulties to analytically address the plurality of claims and questions of justification that arise in the public sphere as critique to the current boundaries of law and citizenship. In contrast, this article take a point of departure in discourse ethics and the sociopolitical practice of rights and argues that Seyla Benhabib's concepts reciprocity and democratic iterations can offer a normative foundation and productive theoretical framework to analyse claims and justifications of asylumseeking children's rights to residence permits in the public sphere. 


\section{DISCUSSION}

This thesis started out by observing that anti-deportation campaigns, protests and controversies concerning the rights of asylum-seeking children to residence permits have become global phenomena. I was struck by the gap between, on one hand, the legal decision making about residence permits as an outcome of democratically enacted laws and, on the other hand, public reasoning about the rights of asylum-seeking children and the persistent criticisms directed at the migration agency and courts for denying residence permits to children. The global recognition of the universal rights of the child, as manifested in the UNCRC, clashed with the state's right to control immigration as a constitutive principle of a modern democracy. In the research field concerned with the rights of asylum-seeking children, a common response has been to call for 'more of children's rights' through standard setting, implementation and monitoring of the UNCRC.

However, in this thesis I have approached the discrepancy between the legal reasoning about the rights of asylum seeking children and the public reasoning about their rights from another direction. At this backdrop, a first aim was formulated to undertake an empirical examination of the controversies around children's rights and immigration control by studying the meaning and uses of children's rights in decision making of the MCA and the contestation of legal decision making in the right claiming of asylum seeking children in Dagens Nyheter. A second aim was to engage theoretically with these issues in dialogue with contemporary political philosophy. In this section, I will take the opportunity to summarise and synthesise some of the main conclusions of the thesis.

\section{Children's rights and immigration control: the establishment and contesta- tion of norms}

About a decade after the establishment of the MCA as the last instance in the new appeals process for alien and citizenship cases in Sweden, my study of its legal arguments has demonstrated how certain norms about the meaning and use of children's rights have been constructed in this particular setting. As is clear from article one, when analysing the decision making of the MCA it soon becomes evident that explicit and developed reasoning about children and their rights in cases of residence permits takes place in relatively few cases. When the court does consider the specific rights of children, it is almost exclusively in relation to the BIP.

A closer analysis of the court's reasoning shows how the BIP commonly functions as a general principle of restriction to ensure that a denial of a residence permit is not in conflict with what is legally regarded as the best 
interests of the child - often without any explicit justification. These findings thus confirm some of the observations made in previous studies about the best interests of the child in other instances in the Swedish asylum process (e.g. Schiratzki, Lundberg and Nilsson). When it comes to the weighing between the best interest of the child and the state interest of immigration control, a general observation is that also immigration control considerations are seldom developed or made explicit (which resembles e.g. the observations made by Sandberg (2014) in her study of the best interest of the child in asylum cases in the Norwegian Supreme Court). Rather the weighing between the interest of the child and the state interest of immigration control is made in far more subtle ways in relation to specific legal procedures, rules and principles and become apparent in for example cases of parent's illegal stay in the country, parent's criminality or with regard to the evidentiary requirements set up for the determination of identity, poor state of health, or adaptation.

It is only in a small minority of the cases that the best interests of the child are in fact given a decisive normative force in the granting of residence permits. It is notable that the rejection of children and their parents does not necessarily result from a failure to take into account children's rights or interests. On the contrary, a series of cases demonstrates that rejections are based on, and carried out in accordance with, children's interests as they are legally interpreted by the court. The open character of the BIP thus enables the court to weaken, strengthen or shift the content and function of a specific norm of children's interests in order to strengthen an argument. In other words, the court's use of children's interests allows for both the granting and the denial of residence permits and can also give legitimacy to decisions that stand in contrast to what the child perceive to be in its own interest. The BIP does normative work in both directions. This conclusion, I suggest, should motivate further empirical studies on the meaning and uses of children's rights as well as the theoretical and normative foundations of children's rights.

In article two, I discussed how asylum-seeking children's rights are given meaning through claims and contestations of the legal norms in Dagens $\mathrm{Ny}-$ heter. Claims about asylum-seeking children in Dagens Nyheter substantially challenge the legal reasoning about, for example, children's poor state of health, the threats to children's well-being posed by the denial of residence permits, children's need to be with their parents and the extent to which children have adapted to Sweden. While some of the public claims draw their normative force from current law by appealing to the UNCRC or legal provisions of the Swedish Aliens Act, other claims are instead grounded in deeply held moral intuitions or public reasoning by children themselves or fellow citizens. These claims offer an alternative approach to the meaning of children's rights that challenges the legal norms about what and who ought 
to be recognised and derive their meaning and normative force from a socialpolitical context and discursive dialogues rather than legal sources as interpreted by courts or the migration agency.

The rights of asylum seeking children in the MCA and DN shows how the shifting strategies of argumentations are intimately related to multifaceted conceptions of children. While the rights of asylum seeking children in the MCA largely is connected to the vulnerability or the 'passivation' of children and their dependency of other actors to protect their rights (In relation to e.g. exceptionally distressing circumstances/humanitarian reasons, and which in a similar way has been observed before by e.g. Bhabha(2001), Fas$\sin (2011)$ and Spijkerboer (2000)), the rights of asylum seeking children described in Dagens Nyheter share some of these characteristics, but challenge also this picture and demonstrate children with political agency, as active subjects of rights with more 'adult-like' abilities to drive the political enforcement of rights him- or herself.

\section{To include what hitherto has been excluded? A discourse ethical approach to children's rights}

In the first chapters of the thesis, I showed how research on children and asylum has largely used the UNCRC as its analytical framework. In many respects, the UNCRC has come to replace theory in childhood and children's rights scholarship, as some critical children's rights scholars have noted. Children's rights are often equated with the UNCRC. In this thesis, I have attempted to find complementary ways to approach children's rights by engaging theoretically in dialogue with contemporary political philosophy.

In article three, Nussbaum's capability approach was examined as an ethical framework to analyse the rights of asylum seeking children. In the article, I argued that the capability approach has the potential to provide an ethical framework for legal and political decision making concerned with securing threshold levels in the asylum process for children. Some challenges remain, however. One of the child-specific challenges that remain to be explored is how a list of children's capabilities is to be legitimately determined and responsive to children's interests and political agency. Dixon and Nussbaum argue for the Capability Approach as a theoretical foundation for children's rights; they also maintain that the special priority of children can be legitimized within the framework of democracy and constitutional law on grounds of vulnerability and cost-effectiveness. The approach overlook, nonetheless, the question of how the specification of children's capabilities (or interests) can be politically and ethically defined, advanced and made accountable to children themselves within a democratic order. The case of the Burundian girl in article three shows how the court judgment and the 
democratic enactment of law define her interest to be with her parents, relatives or corresponding institution in her home-country. A denial of residence permit would not be in conflict with her best interests, while she herself claim a right to stay in the Sweden on grounds of adaptation and risks in her homecountry in case of deportation. According Dixon and Nussbaum, the interests and capabilities of children still ought to be specified and advanced primarily by other actors than children themselves. But if we take Nussbaum's idea of the power of self-definition seriously, how can we, for example, understand the girl from Burundi? As Nussbaum puts it: "The crucial good societies should be promoting for their people is a set of opportunities or substantial freedoms, which people then may or may not exercise in action: the choice is theirs. It thus commits itself to respect for people's powers of self-definition" $(2011,18)$. What does it mean to be responsive to children's political agency and children's interests with respect to their powers of selfdefinition?

In article four, I relate to Benhabib's discourse ethics as an alternative analytical lens, and suggest that her concepts of reciprocity and democratic iterations can offer a productive normative framework for children's rights. Reciprocity offers a moral foundation that potentially can include non-citizens and children in a discursive dialogue in which 'I can justify to you with good reasons that you and I should respect each other's reciprocal claims'. Democratic iterations can in this respect fulfil important functions to enhance democratic legitimacy and respond to some of the critical challenges that the controversies around asylum-seeking children's rights raise.

The discourse ethical approach I put forth in article four, finds its normative sources in discursive dialogues and democratic reflexivity in the public sphere. While some claims from the public sphere can appear as alien to the current law, I suggest, following Lindahl, that these possess a normative potential for questioning the boundaries of the law, which in turn may make possible new ways of drawing the boundaries differently. This is not the same as saying that all individual interests and claims by asylum-seeking children that occur in the public sphere ought to be recognised by law. Rather, this shows how democratic iterations can pave the way for more well-reasoned arguments that include claims that are recognised in discursive dialogues but that hitherto has been excluded from law.

\section{Some reflections on the study of children's rights}

In this thesis, I have discussed new ways of empirically and theoretically approaching children's rights in the context of asylum and immigration control. For this purpose, it has been necessary to cross disciplinary boundaries. As discussed in chapter five, I have particularly sought to bring political theory and political philosophy into the field of childhood studies and children's rights studies. Since they emerged a couple of decades ago, these fields have 
been characterised by inter- or multi-disciplinarity and have continuously been enriched by the communication between diverse disciplines. But this has not so much been the case with political philosophy. This has affected the ways in which children's rights and migration issues have been approached in recent years. In a similar way, mainstream legal and political theory has for many years marginalised the category of the child. This is despite the fact that children constitute a significant part of the world population and are a constitute a large group target of human rights politics and law. It also appears as though the broad empirical knowledge base about children and childhood that has grown out of the expanding field of childhood studies over the last few decades can provide essential input for the formulation and framing of the political-theoretical debate about children.

In chapter two, I presented the socio-political practice of rights as way of studying the rights claims of asylum-seeking children. Such a perspective may, I suggest, have wider consequences for the study of children's rights. When it comes to the normative issues, to approach children's rights within a framework of the UNCRC can arguably be one important approach to the analysis of the rights of children. But what I show in article two and four is how children's rights as a socio-political practice and discourse ethics can offer important complements to children's rights as defined by international or domestic law, regarding both how and where to study children's rights. Not only the meaning and uses of rights as enshrined in positive law, but also as given meaning through claim making and political mobilisation.

Although this thesis has been particularly focused on the rights of asylum seeking children, my hope is that it has opened up for new ways and possibilities for future studies on children's rights, not only in this context, but also with regard to a range of other issues where children's rights come at play. 


\section{REFERENCES}

Andersson, Bridget. 'Where's the harm in that? Immigration Enforcement, Trafficking and the Protection of Migrants' Rights'. American Behavioral Scientist 56, No. 9 (2012): 1241-57.

Archard, David. Children: Rights and Childhood. 3rd ed. Abingdon: Routledge, 2015.

Archard, David and Colin Macleod. The Moral and Political Status of Children. Oxford: Oxford University Press, 2002.

Archard, David and Marit Skivenes. 'Balancing a Child's Best interests and a Child's Views'. International Journal of Children's Rights, 17 (2009): 1-21.

Arendt, Hanna. 'Reflections on Little Rock'. Dissent 6, No. 1 (1959): 4556.

—. The Origins of Totalitarianism Mariner Brooks, 1973.

Avllsup, Ahn. Religious Ethics and Migration: Doing Justice to Undocumented Workers. Abingdon: Routledge, 2014.

Bader, Veit. 'The Ethics of Immigration'. Constellations 12, No. 3 (2005): 331-61

Bader, Veit and Sawitri Saharso. 'Introduction: Contextualized Morality and Ethno-Religious Diversity'. Ethical Theory and Moral Practice 7, No. 2 (2004): 107-15.

Bak Maren and Kerstin Von Brömssen (eds.). Barndom och Migration. Umeå: Borea, 2013.

Balagopalan, Sarada. Inhabiting Childhood: Children, Labour and Schooling in Postcolonial India. Basingstoke: Palgrave Macmillan, 2014.

Baynes Kenneth. 'Discourse ethics and the political conception of human rights'. Ethics \& Global Politics 2, No. 1 (2009): 1-21.

Beitz, Charles. The Idea of Human Rights. Oxford: Oxford University Press, 2011.

Benhabib, Seyla. Situating the Self - gender, community and postmodernism in contemporary ethics. New York: Routledge, 1992.

- The Rights of Others: Aliens, Residents and Citizens. Cambridge: University Press, 2004.

- Dignity in Adversity: Human Rights in Troubled Times. Cambridge: Polity Press, 2011.

—. 'Reason-Giving and Rights-Bearing: Constructing the Subject of Rights'. Constellations 20, No. 1 (2013): 38-50.

Bhabha, Jaqueline. 'Minors or Aliens? Inconsistent State Intervention and Separated Child Asylum-Seekers'. European Journal of Migration and Law 3 Nos. 3-4 (2001): 283-314. 
—. 'Arendt's Children: Do Today's Migrant Children Have a Right to Have Rights?'. Human Rights Quarterly 31, No. 2 (2009): 410-51.

- Child Migration and Human Rights in a Global Age. Princeton, New Jersey: Princeton University Press, 2014.

Biggeri, Mario, Jérôme Ballet and Flavio Comim (eds.). Children and the Capability Approach. Basingstoke: Palgrave Macmillan, 2011.

Bosniak, Linda. The Citizen and the Alien: Dilemmas of Contemporary Membership. Princeton, New Jersey: Princeton University Press, 2008.

Brennan, Samantha. 'Children's Choices or Children's Interests: Which Do Their Rights Protect?' In The Moral and Political Status of Children, ed. David Archard and Colin Macleod, Oxford: Oxford University Press, 2002.

Brennan, Samantha and Robert Noggle. 'John Rawls's Children'. In The Philosophers Child: Critical Perspectives in the Western Tradition, ed. Gareth B. Matthews and Susan M Turner, 203-32. Rochester: University of Rochester Press, 1998.

Brighouse, Harry. 'What Rights (If Any) Do Children Have?' In The Moral and Political Status of Children, ed. Archard and Macleod, 31-52. Oxford: Oxford University Press, 2002.

Buchanan, Allen and Kristen Hellser. 'Specifying the Content of the Human Right to Health Care'. In Medicine and Social Justice: Essays on the Distribution of Health Care, ed. Rosamond Rhodes, Margaret P. Battin and Anita Silvers, 84-101. Oxford: Oxford University Press, 2002.

Carens, Joseph. 'Aliens and citizens: The case for open borders'. Review of Politics 49 (1987): 250-73.

- 'A Contextual Approach to Political Theory'. Ethical Theory and Moral Practice 7 (2004): 117-32.

- The Ethics of Immigration. Oxford: Oxford University Press, 2013.

Cohen, Joshua. 'Minimalism about Human Rights: The Most We Can Hope For'. The Journal of Political Philosophy 12 (2004): 190-213.

Cruft, Rowan, S. Matthew Liao and Massimo Renzo. Philosophical foundations of human rights. Oxford: Oxford University Press, 2015.

Cunningham, Hugh. Children and Childhood in Western Society since 1500. 2nd edn. Harlow: Pearson Education, 2005.

Dembour, Marie-Benedicte. 'What Are Human Rights? Four Schools of Thought'. Human Rights Quarterly 32, No. 1 (2010): 1-20.

- When Humans Become Migrants: Study of the European Court of Human rights with an Inter-American Counterpoint. Oxford: Oxford University Press, 2015.

Dobson, Madeleine E. 'Unpacking children in migration research'. Children's Geographies 7, No. 3 (2009): 355-60. 
Dworkin, Ronald. Taking Rights Seriously. Cambridge, MA: Harvard University Press 1977.

Eastmond, Marita. 'Egalitarian Ambitions, Constructions of Difference: The Paradoxes of Refugee Integration in Sweden'. Journal of Ethnic and Migration Studies 37 (2011): 277-95.

Eastmond, Marita and Henry Ascher. 'In the Best Interest of the Child? The Politics of Vulnerability and Negotiations for Asylum in Sweden'. Journal of Ethnic and Migration Studies 37, No. 8 (2011): 1185-200.

Ensor, Marisa O. and Eläbieta M. Goździak (eds.). Children and Migration: At the Crossroads of Resiliency and Vulnerability. Basingstoke: Palgrave Macmillan, 2010.

Fairclough, Isabella and Norman Fairclough. Political Discourse Analysis: A Method for Advanced Students. Abingdon: Routledge, 2012.

Farson, Richard. Birthrights: a bill of rights for children. Harmondsworth: Penguin Books, 1974.

Fass, Paula. 'A Historical Context for the United Nations Convention on the Rights of the Child'. Annals of the American Academy of Political and Social Science 633 (2011): 17-29.

Fassin, Didier, Humanitarian Reason: A Moral History of the Present, University of California Press 2011.

Ferguson, Lucinda. 'Not Merely Rights for Children but Children's Rights: The Theory Gap and the Assumption of the Importance of Children's Rights'. International Journal of Children's Rights 21, No. 2 (2013): 177-208.

Forst, Rainer. 'The Basic Right to Justification: Toward a Constructivist Conception of Human Rights'. Ethics 120 (2010): 711-40.

- Justification and Critique: Towards a Critical Theory of Politics. London: Polity, 2013.

Fraser, Nancy. 'Rethinking the Public Sphere: A Contribution to the Critique of Actually Existing Democracy'. Social Text 25/26 (1990): 5680.

Fraser, Nancy and Axel Honneth. Redistribution or recognition? A political-philosophical exchange, trans. Joel Golb, James Ingram and Christiane Wilke. London: Verso Books, 2003.

Freeman, Michael. 'The future of children's rights'. Children \& Society 14 (2000): 277-93.

(ed.). Children's Rights. 2 vols. Aldershot, UK and Burlington, VT: Ashgate, 2004.

- (ed.). Children's Rights: Progress and Perspectives - Essays from the International Journal of Children's Rights. Leiden: Martinnus Nijhoff Publishers, 2011. 
Gardner, Kathy. 'Transnational Migration and the Study of Children: An Introduction'. Journal of Ethnic and Migration studies 38, No. 6 (2012): 889-912.

Gibney Matthew J. 'Is Deportation a Form of Forced Migration?'. Refugee Survey Quarterly 32, No. 2 (2013): 116-29.

Gibney Matthew J. and R. Hansen. 'Deportation and the liberal state: the forcible return of asylum seekers and unlawful migrants in Canada, Germany and the United Kingdom'. New Issues in Refugee Research. Working Paper No. 77 (2003).

Gil-Bazo, María-Teresa, 'Asylum as a General Principle of International Law', International Journal of Refugee Law 27, No. 1 (2015): 3-28.

Giner, Clotilde. 'The Politics of Childhood and Asylum in the UK'. Children and Society 21 (2007): 249-60.

Griffin, James. 'Do children have rights?'. In The Moral and Political Status of Children, Archard and Macleod, 19-30. Oxford: Oxford University Press, 2008.

Habermas, Jürgen. The Structural Transformation of the Public Sphere: An inquiry into a category of Bourgeois Society. Cambridge: Polity Press, 1989.

Hafen, Bruce C. 'Children's Liberation and the New Egalitarianism: Some Reservations About Abandoning Youth to Their "Rights"'. BYU Law Review 605, No. 3 (1976): 605-58.

Hanson, Karl and Olga Nieuwenhuys. Reconceptualizing Children's rights in International Development: Living Rights, Social Justice, Translations. New York: Cambridge University Press, 2013.

Hart, H.L.A. Essays on Bentham: Studies in Jurisprudence and Political Theory. Oxford: Clarendon Press, 1982.

Hedlund, Daniel. "“Beard boys": Standing in the way of a transformation of the self'. In Invisible boy: The making of contemporary masculinities, ed. C. Hällgren, E. Dunkels and G-M. Frånberg, 83-94. Umeå: Umeå universitet, 2015.

—. 'Drawing the limits: Unaccompanied minors in Swedish asylum policy and procedure'. PhD Thesis. Stockholm University, 2016. Available at: http://urn.kb.se/resolve?urn=urn:nbn:se:su:diva-127091.

Holt, John. Escape from Childhood: The Needs and Rights of Children. Oxford: Oxford University Press, 1973.

Hägglund, Solveig and Harcourt, Debora. 'Turning the UNCRC upside down: a bottom-up perspective on children's rights', International Journal of Early Years Education 21, No. 4 (2013): 286-299.

Isin, Engin F. and Bryan Turner. 'Citizenship Studies: An Introduction'. In Handbook of Citizenship Studies, ed. Engin F. Isin and Bryan S. Turner, 1-10. London: Sage, 2002. 
James, Allison, Chris Jenks and Alan Prout. Theorizing childhood. Cambridge: Polity Press, 1998.

Josefsson, Jonathan. 'Children as Moral Subjects in Ethics of Immigration'. Proceedings from the $49^{\text {th }}$ Societas Ethica Annual Conference, 23-26 August 2012, 147-160, http://www.ep.liu.se/ecp/097/013/ecp12097013.pdf, accessed 5 December 2016.

—. 'Children's Rights to Asylum and the Capabilities Approach'. Ethical Perspectives 23, No. 1 (2016): 101-30.

—. 'Children's Rights to Asylum in the Swedish Migration Court of Appeal'. International Journal of Children's Rights (accepted).

—_. "We beg you, let them stay!”: right claims of asylum-seeking children as a socio-political practice'. Childhood. Prepublished 7 November 2016, DOI:10.1177/0907568216674785.

Kallio, Kirsi Paulina. 'Performative bodies, tactical agents and political selves: rethinking the political geographies of childhood'. Space \& Polity 11, No. 2 (2007): 121-36.

Kallio, Kirsi Paulina. and Jouni Häkli. 'Are there politics in childhood?'. Space \& Polity 15, No. 1 (2011): 21-34.

—. 'Children and Young People's Politics in Everyday Life'. Space \& Polity 17, No. 1 (2013): 1-16.

Kehily Mary Jane (ed.). An Introduction To Childhood Studies, Maidenhead: McGraw-Hill Education, 2008.

Koskenniemi, Martti. From Apology to Utopia: The Structure of International Legal Argument. Cambridge: Cambridge University Press, 2005.

Koskenniemi, Martti. 'The politics of international law - 20 years later', The European Journal of International Law 20, No. 1 (2009)

Kromhout, Mariska. 'Return of Separated Children: The Impact of Dutch Policies'. International Migration 49, No. 5 (2009): 25-47.

Kymlicka, Will. Multicultural Citizenship: A Liberal Theory of Minority Rights. Oxford: Clarendon Press, 1995.

Laoire, Caitríona Ní, Naomi Tyrrell, Fina Carpena-Méndez and Allen White (eds.). 'Special issue: Childhood and migration: mobilities, homes and belongings'. Childhood 17, No. 2 (2010): 155-287. (eds.). 'Special issue: Transnational Migration and Childhood'. Journal of Ethnic and Migration studies 37, No 8. (2011): 1159-293.

Lee, Nick. Childhood and society: Growing up in an age of uncertainty. Buckingham: Open University Press, 2001.

Liebel, Manfred. A Will of their Own: Cross-Cultural Perspectives on Working Children. London: Zed Books, 2004. 
- Children's Rights from Below. New York: Palgrave Macmillan, 2012.

Lind, Jacob. 'The duality of children's political agency in deportability'. Politics, Prepublished 6 September 2016, DOI:

$10.1177 / 0263395716665391$.

Lindahl, Hans. Fault Lines of Globalization: Legal Order and the Politics of A-Legality. Oxford: Oxford University Press, 2013.

Lister, Ruth. 'Why Citizenship: where, when and how children?' Theoretical Inquiries in Law 8, No. 2 (2007): 693-718.

Locke, John. Essay concerning human understanding. Book 2, chapter 1, section 2 .

- Two Treatises of Government. Cambridge: Cambridge University Press, 1988.

Lundberg, Anna. 'Barns rätt att komma till tals i asylprocessen - om likheter och diskrepanser mellan policy och praktikin current themes'. In Asylum Seekers in Sweden - A Just and Dignified Reception for Children and Adults?, ed. Björn Fryklund and Anna Lundberg. Malmö: Malmö Institute for Studies of Migration, Diversity and Welfare (MIM) and Department of International Migration and Ethnic Relations (IMER) Malmö University, 2009.

—. 'The Best Interests of the Child Principle in Swedish Asylum Cases: The Marginalization of Children's Rights'. Journal of Human Rights Practice 3, No. 1 (2011): 49-70.

—. 'Barn i den svenska asylprocessen'. In Barndom och Migration, ed. Bak and Brömssen, 47-78. Umeå: Borea, 2013.

MacCormick, Neil. 'Children's Rights: a Test Case for Theories of Right'. Legal Right and Social Democracy: Essays in Legal and Political Philosophy. Oxford: Oxford University Press, 1984.

Mahmoudi, Said, Pernilla Leviner, Anna Kaldal and Katrin Lainpelto (eds.). Child-friendly Justice: A Quarter of a Century of the UN Convention on the Rights of the Child. Leiden: Brill Nijhoff, 2015.

Margolin C.R. 'Salvation versus Liberation: The Movement for Children's Rights in a Historical Context'. Social Problems 25, No. 4 (1978): 441-52.

Marshall, T.H. Citizenship and Social Class: and Other Essays. Cambridge: Cambridge University Press, 1950.

Marshall, Dominique. 'Reconstruction Politics, the Canadian Welfare State and the Ambiguity of Children's Rights, 1940-1950'. In Uncertain Horizons. Canadians and their World in 1945, ed. Greg Donaghy ed., 261-83. Ottawa: Canadian Committee for the History of the Second World War, 1996.

Matthews, Gareth B. \& Susan M. Turner (eds.). The Philosopher's Child: Critical Perspectives in the Western Tradition. Rochester: University of Rochester Press, 1998. 
Miller, David. 'In Defense of Nationality'. Journal of Applied Philosophy 10, No. 1 (1993): 3-16.

—. 'Nationality: Some Replies'. Journal of Applied Philosophy 14, No. 1 (1997): 69-82.

- 'On Nationality and Global Equality: A reply to Holtug'. Ethics and Global Politics 4 (2011): 165-71.

- Strangers in Our Midst; The Political Philosophy of Immigration (Harvard University Press 2016).

Montgomery, Heather. 'Children's Rights'. In Oxford Bibliographies: Childhood Studies, ed. Heather Montgomery. Oxford: Oxford University Press, 2015.

Moody, Zoe. 'Transnational treaties on children's rights: Norm building and circulation in the twentieth century'. Paedagogica Historica 50, Nos. 1-2 (2014): 151-64.

Moosa-Mitha, Mehmoona. 'A Difference-Centred Alternative to Theorization of Children's Citizenship Rights'. Citizenship Studies 9, No. 4 (2005): 369-88.

Moyn, Samuel. The Last Utopia: Human Rights in History. Cambridge, MA: Harvard University Press, 2010.

- Human Rights and the Uses of History. London: Verso Books, 2014.

Muftee, Mehek. "That will be your home" Resettlement preparations for children and youth from the Horn of Africa. PhD Thesis. Linköping University, 2014.

Nakata, Sana. 'Elizabeth Eckford's Appearance at Little Rock: The Possibility of Children's Political Agency'. Politics 28, No. 1 (2008): 19-25.

- Childhood Citizenship, Governance and Policy: The Politics of Becoming Adult. Abingdon: Routledge, 2015.

Nickel, James. Making Sense of Human Rights. Oxford: Blackwell, 2007.

Nilsson, Eva. Barn i Rättens Gränsland: om barnperspektiv vid prövning om uppehållstillstånd. Uppsala: Iustus, 2007.

Noll, Gregor. 'Why Human Rights Fail to Protect Undocumented Migrants'. European Journal of Migration and Law 12 (2010): 241-72.

Nozick, Robert. Anarchy, State, and Utopia. New York: Basic Books, 1974.

Nussbaum, Martha. Frontiers of Justice: disability, nationality, species membership. Cambridge, MA: Harvard University Press, 2007.

Nussbaum, Martha and Rosalind Dixon. 'Children's Rights and a Capabilities Approach: The Question of Special Priority'. Cornell Law Review 97 (2012): 549-94.

O’Neill, Onora. 'Children's Rights and Children's Lives'. Ethics 98, No. 3 (1988): 445-63. 
Orellana, Marjorie Faulstich, Barrie Thorne, Anna Chee, Wan Shun Eva Lam. 'Transnational childhoods: The participation of children in processes of family migration'. Social Problems 48, No. 4 (2001): 57291.

Ottosson, Lisa and Anna Lundberg. “"People Out of Place”? Advocates' Negotiations on Children's Participation in the Asylum Application Process in Sweden'. International Journal of Law, Policy and the Family 27, No. 2 (2013): 266-87.

Platt, Anthony. 'The Rise of the Child-Saving Movement: A Study in Social Policy and Correctional reform'. Annals of the American Academy of Political and Social Science 381 (1969): 21-38.

Quennerstedt, Ann. 'Children's Rights Research Moving into the Future Challenges on the Way Forward'. International Journal of Children's Rights 21 (2013): 233-47.

Rawls, John. A Theory of Justice. Cambridge, MA: Harvard University Press, 1971.

—. 'The Idea of Public Reason Revisited'. The University of Chicago Law Review 64, No. 3 (1997): 765-807.

- The Law of Peoples with 'The Idea of Public Reason Revisited'. Cambridge, MA: Harvard University Press, 2001.

Raz, Joseph. The Morality of Freedom. Oxford: Oxford University Press, 1986.

Reynaert, Didier, Maria Bouverne-De Bie and Stijn Vandevelde. 'Between "believers" and "opponents": Critical discussions on children's rights'. International Journal of Children's Rights 20, No. 1 (2012): 155-68.

—. 'A review of children's rights literature since the adoption of the United Nations convention on the rights of the child'. Childhood 16, No. 4 (2009): 518-34.

Reynolds, Pamela, Olga Nieuwenhuys and Karl Hanson. 'Refractions of children's rights in development practice: a view from anthropology Introduction'. Childhood 13, No. 3 (2006): 291-302.

Risse, Mattias. 'Immigration, Ethics and the Capabilities Approach'. Human Development Research Paper 2009/34. United Nations Development Program.

Robeyn, Ingrid. 'The Capability Approach'. Stanford Encyclopedia of Philosophy (Winter 2016 Edition), Edward N. Zalta (ed.), forthcoming URL = https://plato.stanford.edu/archives/win2016/entries/capabilityapproach/.

Robeyn, Ingrid and Harry Brighouse (eds.). Measuring Justice: Primary Goods and Capabilities. Cambridge: Cambridge University Press, 2010.

Sandberg, Kirsten. 'The Role of National Courts in Promoting Children's Rights'. International Journal of Children's Rights 22 (2014): 1-20. 
Sandin, Bengt. 'Children and the Swedish Welfare State: From Different to Similar'. In Reinventing Childhood after World War II, eds. Paula S. Fass and Michael Grossberg, 110-38. Philadelphia: University of Pennsylvania Press, 2012.

- . 'History of Children's Well-Being'. In Handbook of Child Well-Being: Theories, methods and policies in global perspective, ed. Asher Ben-Arieh, Ivar Frønes, Ferran Casas and Jill E. Korbin, 31-86. Dordrecht: Springer, 2013.

Schapiro, Tamar. 'What is a child?' Ethics 109 (1999): 715-38.

Schiratzki, Johanna. 'The Best Interests of the Child in the Swedish Aliens Act'. International Journal of Law, Policy and the Family 14, No. 3 (2000): 206-25.

Schotl, Bas. On the Right of Exclusion: Law, Ethics and Immigration Policy. Abindgon: Routledge, 2012.

Schrag, Francis. 'Rights over children', Journal of Value Inquiry 7, No. 2 (1973): 96-105.

- 'The Child's Status in the Democratic State'. Political Theory 3, No. 4 (1975): 441-57.

Schweiger Gottfried, Gunter Graf and Mar Cabezas (eds.). 'Special Issue: Justice and Disadvantages during Childhood: What Does the Capability Approach Have to Offer?'. Ethical Perspectives 23 No. 1 (2016): 101-30.

Seglow, Jonathan. 'The Ethics of Immigration'. Political Studies Review 3, No. 3 (2005): 317-34.

Smith, Carmel and Sheila Greene. Key Thinkers in Childhood Studies: Reflections on the Making of a Field. Bristol: Policy Press, 2014.

Smyth, Ciara. European Asylum Law and the Rights of the Child. Abingdon: Routledge, 2014.

Smyth, Ciara. 'The Common European Asylum System and the Rights of the Child: An Exploration of Meaning and Compliance'. PhD Thesis. Leiden University, 2013.

Spijkerboer, Thomas, Gender and Refugee Status. Aldershot: Ashgate Publishing Limited, 2000.

Stammers, Neil. Human Rights and Social Movements. London: Palgrave Macmillan, 2009.

Stern, Rebecca. Ny utlänningslag under lupp. Stockholm: Röda Korset, 2008.

— . 'Skyddsbehövande i övrigt - ett svårtolkat begrepp?'. In Asylum Seekers in Sweden - A Just and Dignified Reception for Children and Adults?, ed. Björn Fryklund and Anna Lundberg, 146-169. Malmö: Malmö Institute for Studies of Migration, Diversity and Welfare (MIM) and Department of International Migration and Ethnic Relations (IMER) Malmö University, 2009. 
Stern, Rebecca Thorburn and Hanna Wikström. Migrationsrätt: skyddsbehov och trovärdighet - bedömning $i$ asylärenden. Stockholm: Liber, 2016.

Stoecklin, Daniel and Jean-Michel Bonvin (eds.). Children's Rights and the Capabilities approach: challenges and prospects. Berlin: Springer, 2014.

Stretmo, Liv. 'Governing the unaccompanied child: Media, policy and practice'. PhD Thesis. Gothenburg University, 2014.

Taylor, Charles. Multiculturalism and the Politics of Recognition. Princeton, New Jersey: Princeton University Press, 1994.

Tobin, John. 'Justifying Children's Rights'. The International Journal of Children's Rights 21, No. 3 (2013): 395-441.

Vitus, Karin and Hilde Lidén. 'The Status of the Asylum-seeking Child in Norway and Denmark: Comparing Discourses, Politics and Practices'. Journal of Refugee Studies 23, No. 1 (2010): 62-81.

Wald, Michael S. 'Children's Rights: A Framework for Analysis'. UCD Law Review 12 (1979): 255-82.

Wall John, 'Human Rights in Light of Childhood'. International Journal of Children's Rights 16 (2008): 523-43.

—. Ethics in Light of Childhood. Washington DC: Georgetown University Press, 2010.

- 'Can democracy represent children? Towards a politics of difference'. Childhood 19, No. 1 (2012): 86-100.

—. 'Why Children and Youth Should Have the Right to Vote: An Argument for Proxy-Claim Suffrage'. Children, Youth and Environments 24, No. 1 (2014): 108-23.

Walzer, Michael. Spheres of Justice: A Defense of Pluralism and Equality. New York: Basic Books, 1983.

Vandenhole, Wouter. 'Children's rights from a legal perspective: Children's rights law'. In Routledge International Handbook of Children's Rights Studies, ed. Wouter Vandenhole, Ellen Desmet, Didier Reynaert and Sara Lembrechts, 27-42. Abingdon: Routledge, 2015.

Vandenhole, Wouter., Ellen Desmet, Didier Reyneart, Sara Lambrechts (eds.). Routledge International Handbook of Children's Rights Studies. Abingdon: Routledge, 2015.

Verhellen E. and F. Spiesschaert (eds.). Ombudswork for children. Leuven: Acco Academic Publishing Company, 1989.

Van Eemerren, Frans H. and Peter Houtlosser (eds.). Argumentation in Practice. John Amsterdam: Benjamins Publishing Company, 2005.

Watters, Charles. Refugee children: Towards the next horizon. Abingdon: Routledge, 2008. 
Wellman, Christopher H. and Philip Cole. Debating the Ethics of Immigration: is there a right to exclude? Oxford: Oxford University Press, 2011.

Wilcox, Shelley. 'The Open Borders Debate on Immigration'. Philosophy Compass 4, No. 5 (2009): 813-21.

Wyness, Michael. Childhood and Society. 2nd ed. Basingstoke: Palgrave, 2012.

Zermatten, Jean. 'Best Interests of the Child'. In Child-friendly Justice: A Quarter of a Century of the UN Convention on the Rights of the Child, ed. Said Mahmoudi et al., 30-42. Leiden: Brill Nijhoff, 2015.

\section{Legal sources:}

Aliens Act 1989 7:11

Convention Relating to the Status of Refugees 1951

European Common Asylum Directive, Directive 2013/32/EU

European Database of Asylum Law, http://www.asylumlawdatabase.eu, accessed 6 December 2016

Gov. Committee Dir. 2007:119

MIG 2009:8

MIG 2010:6

Optional Protocol to the Convention on the Rights of the Child on the involvement of children in armed conflict (OPAC), A/RES/54/263, http://www.ohchr.org/EN/ProfessionalInterest/Pages/OPACCRC.aspx, accessed 27 November 2016.

Optional Protocol to the Convention on the Rights of the Child on the sale of children, child prostitution and child pornography (OPSC);

A/RES/54/263, http://www.ohchr.org/EN/ProfessionalInterest/Pages/OPSCCRC.aspx, accessed 27 November 2016.

Optional Protocol to the Convention on the Rights of the Child on a communications procedure (CP), A/RES/66/138, http://www.ohchr.org/EN/ProfessionalInterest/Pages/OPICCRC.aspx, accessed 27 November 2016.

Prop. 1996/97:25

Protocol Relating to the Status of Refugees 1967

SOU 2004/05:170

SOU 2016:19, The Child Rights Inquiry (In Swedish: Barnrättighetsutredningen)

SFS 1971:291

SFS 2009:783

Swedish Aliens Act 2005:716 (SFS 2005:716) 
Swedish Aliens Act 1989:529 (SFS 1989:529)

Swedish Jurisprudence, Official database of the Swedish National Courts Administration, http://www.rattsinfosok.dom.se/lagrummet/, accessed 6 December 2016. 


\section{Papers}

The articles associated with this thesis have been removed for copyright reasons. For more details about these see:

http://urn.kb.se/resolve?urn=urn:nbn:se:liu:diva-133238 